\title{
Impacts of the 2014-2015 Holuhraun eruption on the UK atmosphere
}

\author{
Marsailidh M. Twigg ${ }^{1}$, Evgenia Ilyinskaya ${ }^{2, a}$, Sonya Beccaceci ${ }^{3}$, David C. Green ${ }^{4}$, Matthew R. Jones ${ }^{1}$, Ben Langford ${ }^{1}$, \\ Sarah R. Leeson ${ }^{1}$, Justin J. N. Lingard ${ }^{5}$, Gloria M. Pereira ${ }^{6}$, Heather Carter ${ }^{6}$, Jan Poskitt ${ }^{6}$, Andreas Richter $^{7}$, \\ Stuart Ritchie $^{3}$, Ivan Simmons ${ }^{1}$, Ron I. Smith ${ }^{1}$, Y. Sim Tang ${ }^{1}$, Netty Van Dijk ${ }^{1}$, Keith Vincent ${ }^{5}$, Eiko Nemitz ${ }^{1}$, \\ Massimo Vieno ${ }^{1}$, and Christine F. Braban ${ }^{1}$ \\ ${ }^{1}$ NERC Centre for Ecology and Hydrology, Bush Estate, Penicuik, EH26 0QB, UK \\ ${ }^{2}$ NERC British Geological Survey, Murchison House, W Mains Rd, Edinburgh, EH9 3LA, UK \\ ${ }^{3}$ Environment Division, National Physical Laboratory, Teddington, London, UK \\ ${ }^{4}$ Environmental Research Group, King's College London, Franklin-Wilkins Building, 150 Stamford Street, \\ London, SE1 9NH, UK \\ ${ }^{5}$ Ricardo Energy \& Environment, The Gemini Building, Fermi Avenue, Harwell, Didcot, OX11 0QR, UK \\ ${ }^{6}$ NERC Centre for Ecology and Hydrology, Lancaster Environment Centre, Library Avenue, Bailrigg, Lancaster, \\ LA1 4AP, UK \\ ${ }^{7}$ Institute of Environmental Physics, University of Bremen, Otto-Hahn-Allee, 28359 Bremen, Germany \\ ${ }^{a}$ now at: School of Earth and Environment, University of Leeds, Leeds, LS2 9JT, UK
}

Correspondence to: Marsailidh M. Twigg (sail@ceh.ac.uk)

Received: 29 February 2016 - Published in Atmos. Chem. Phys. Discuss.: 30 March 2016

Revised: 12 August 2016 - Accepted: 24 August 2016 - Published: 14 September 2016

\begin{abstract}
Volcanic emissions, specifically from Iceland, pose a pan-European risk and are on the UK National Risk Register due to potential impacts on aviation, public health, agriculture, the environment and the economy, from both effusive and explosive activity. During the 2014-2015 fissure eruption at Holuhraun in Iceland, the UK atmosphere was significantly perturbed. This study focuses one major incursion in September 2014, affecting the surface concentrations of both aerosols and gases across the UK, with sites in Scotland experiencing the highest sulfur dioxide $\left(\mathrm{SO}_{2}\right)$ concentrations. The perturbation event observed was confirmed to originate from the fissure eruption using satellite data from GOME2B and the chemical transport model, EMEP4UK, which was used to establish the spatial distribution of the plume over the UK during the event of interest. At the two UK European Monitoring and Evaluation Program (EMEP) supersite observatories (Auchencorth Moss, SE Scotland, and Harwell, SE England) significant alterations in sulfate $\left(\mathrm{SO}_{4}^{2-}\right)$ content of $\mathrm{PM}_{10}$ and $\mathrm{PM}_{2.5}$ during this event, concurrently with evidence of an increase in ultrafine aerosol most likely due to nucleation and growth of aerosol within
\end{abstract}

the plume, were observed. At Auchencorth Moss, higher hydrochloric acid $(\mathrm{HCl})$ concentrations during the September event $\left(\max =1.21 \mu \mathrm{g} \mathrm{m}^{-3}\right.$, cf. annual average $0.12 \mu \mathrm{g} \mathrm{m}^{-3}$ in 2013), were assessed to be due to acid displacement of chloride $\left(\mathrm{Cl}^{-}\right)$from sea salt $(\mathrm{NaCl})$ to form $\mathrm{HCl}$ gas rather than due to primary emissions of $\mathrm{HCl}$ from Holuhraun. The gas and aerosol partitioning at Auchencorth Moss of inorganic species by thermodynamic modelling confirmed the observed partitioning of $\mathrm{HCl}$. Using the data from the chemical thermodynamic model, ISORROPIA-II, there is evidence that the background aerosol, which is typically basic at this site, became acidic with an estimated $\mathrm{pH}$ of 3.8 during the peak of the event.

Volcano plume episodes were periodically observed by the majority of the UK air quality monitoring networks during the first 4 months of the eruption (August-December 2014), at both hourly and monthly resolution. In the low-resolution networks, which provide monthly $\mathrm{SO}_{2}$ averages, concentrations were found to be significantly elevated at remote "clean" sites in NE Scotland and SW England, with recordhigh $\mathrm{SO}_{2}$ concentrations for some sites in September 2014. 
For sites which are regularly influenced by anthropogenic emissions, taking into account the underlying trends, the eruption led to statistically unremarkable $\mathrm{SO}_{2}$ concentrations (return probabilities $>0.1, \sim 10$ months). However, for a few sites, $\mathrm{SO}_{2}$ concentrations were clearly much higher than has been previously observed (return probability $<0.005$, $>3000$ months). The Holuhraun Icelandic eruption has resulted in a unique study providing direct evidence of atmospheric chemistry perturbation of both gases and aerosols in the UK background atmosphere. The measurements can be used to both challenge and verify existing atmospheric chemistry of volcano plumes, especially those originating from effusive eruptions, which have been underexplored due to limited observations available in the literature. If all European data sets were collated this would allow improved model verification and risk assessments for future volcanic eruptions of this type.

\section{Introduction}

Volcanic emissions perturb atmospheric composition in the troposphere (Bobrowski et al., 2007; Horrocks et al., 2003; Martin et al., 2008; Oppenheimer et al., 2010, 2006; von Glasow, 2010) via emissions of ash and/or gases and aerosols to the atmosphere, particularly during active eruptions. These emissions can directly impact humans and ecosystems (Thordarson and Self, 2003) as well as have indirect effects on climate (Gettelman et al., 2015; Schmidt et al., 2012, 2014). The injection of sulfur dioxide $\left(\mathrm{SO}_{2}\right)$ and sulfate $\left(\mathrm{SO}_{4}^{2-}\right)$, as well as aerosol in the form of ash, into the stratosphere are large events which can have global effects, as shown by the cases of Mount Pinatubo and El Chichon where atmospheric perturbation and climate forcing were observed (Grainger and Highwood, 2003). Stratospheric perturbation generally only occurs as a result of explosive eruptions, as they have enough force to break through the tropopause to the stratosphere. In these types of eruptions, deposition of atmospheric components to the surface is diffuse and long term.

Atmospheric chemistry in the lower troposphere and in particular the boundary layer with resultant earth surface effects is frequently associated with effusive eruptions. The 1783-1784 fissure eruption of Laki is considered the "type" eruption for a long-lasting effusive eruption on Iceland. The Laki eruption dynamics and emission masses have been characterized in several papers (e.g. Thordarson and Self, 2003). In these eruptions, there is a long-term flow of lava and limited ash generation with the result of a long-term input of gas-phase emissions in the lower parts of the troposphere. This is contrasted with the shorter-term punctuated emissions from an explosive eruption. It is noted that eruptions maybe a mixture of both effusive and explosive, e.g. Stromboli as described by Ripepe et al. (2007). The impact of effusive eruptions on the troposphere at both local and regional scales, is most frequently studied in responsive mode, post-eruption initiation. As technology and instrumentation has developed and global air quality monitoring effort have increased too, this has resulted in some cases where background conditions and the evolution of distal volcanic plumes can be now be studied.

Volcanic plumes contain elevated quantities of reactive sulfur species, primarily in the form of $\mathrm{SO}_{2}$. There is still great debate whether $\mathrm{SO}_{4}^{2-}$ aerosol is directly emitted from volcanos or is a result of rapid formation once it enters the atmosphere, which is already detectable at the crater rim (von Glasow et al., 2009). In distal plumes, it is thought that $\mathrm{SO}_{2}$ will eventually form $\mathrm{SO}_{4}^{2-}$ through the reaction with the $\mathrm{OH}$ radical, though $\mathrm{SO}_{2}$ will also be removed from the troposphere through wet and dry deposition to the surface too. Quantifying the relative emission abundance of $\mathrm{SO}_{2}$ and $\mathrm{SO}_{4}^{2-}$ and the oxidative aging of the plume converting $\mathrm{SO}_{2}$ to $\mathrm{SO}_{4}^{2-}$ has been attempted previously, for example by Satsumabayashi et al. (2004), but there is a very limited number of studies (Hunton et al., 2005; Rose et al., 2006; Mather et al., 2003; Kroll et al., 2015; Boulon et al., 2011; Satsumabayashi et al., 2004) which have quantified gas and aerosol composition beyond sulfur species and provided evidence of tropospheric chemistry of distal plumes including halogen chemistry and particle growth (Boulon et al., 2011).

Previously it was thought that the chemistry of volcanic plumes in the troposphere was dominated by the oxidation of $\mathrm{SO}_{2}$, but this changed when Bobrowski et al. (2003) observed in addition a relatively large emission of the bromine oxide $(\mathrm{BrO})$ radical in a plume from Soufriéré Hills (von Glasow et al., 2009). It is now known that emissions of hydrochloric acid $(\mathrm{HCl})$, hydrogen fluoride $(\mathrm{HF})$ and hydrogen bromide $(\mathrm{HBr})$ can drive the chemistry within volcanic plumes, though the presence of halogens is determined by the chemical signature of each individual volcanic system. The rates of atmospheric processing driven by halogens in volcanic plumes are of great interest, as it is thought that reaction rates may differ significantly from that observed in the background atmosphere, which is more frequently studied. This is due to higher temperatures and a unique chemical composition volcanic plumes, which is potentially able to generate radicals. It is important to study the atmospheric processing within volcanic plumes as it determines the fate and deposition of acidic compounds contained within the plume (Aiuppa et al., 2007). Studies have shown that the ratios of $\mathrm{SO}_{2} / \mathrm{HCl}$ remain constant in a distal plume but the ratio decreases in the presence of clouds, as the gases dissolve in order of solubility and therefore $\mathrm{HCl}$ will dissolve first in the presence of clouds, though the studies mentioned were carried out within tens of kilometres from the source (von Glasow et al., 2009; Burton et al., 2001; Aiuppa et al., 2007).

One aspect which is challenging for scientists is capturing both the physical characteristics and the chemical composition of volcanic plumes after mixing with the background 
in the distal plume, particularly at long distances away from eruption source. In the case presented the distal plume was $\sim 1000 \mathrm{~km}$ from its source in Iceland. The primary chemical components of volcano plumes measured are $\mathrm{SO}_{2}$ and $\mathrm{SO}_{4}^{2-}$, but there are many other gases emitted. Other studies have in addition measured the full chemical composition of particulate matter (PM), e.g. Mather et al. (2003) and Martin et al. (2008), and more recently indirect measurements of aerosol properties from satellites have been undertaken (Ebmeier et al., 2014). Aiuppa (2009) and Pyle and Mather (2009) published reviews of the literature in the area of chemical degassing with a focus on emitted halogen chemicals which can occur both in the gas and aerosol phase. In most studies the ratios of $\mathrm{HCl}$ and $\mathrm{HF}$ to $\mathrm{SO}_{2}$ are reported rather than the absolute concentration. Similarly the other sulfur gases, $\mathrm{H}_{2} \mathrm{~S}$ and $\mathrm{COS}$, are studied but less frequently. The Witham et al. (2015) report summarized the halogen acid and $\mathrm{H}_{2} \mathrm{~S}$ ratios from the literature. It was noted that predominantly measurements are made close to the emission source or at a surface position downwind from the eruption either by remote sensing or direct sampling with offline analysis methods.

Only a few modelling studies (e.g. Witham et al., 2015; Schmidt et al., 2015) and measurement approaches (Kroll et al., 2015; Businger et al., 2015) have assessed the atmospheric chemistry with an air quality impact focus. Complex perturbation of atmospheric ozone and other oxidants has been studied both in the stratosphere and troposphere but with only a limited number of observation studies. Recent reviews have indicated there is still much to be done (Mather, 2015; von Glasow et al., 2009) to understand the input of volcano emissions and the perturbation to the atmosphere.

To date there is only one study which has demonstrated nucleation and particle growth in a distal volcanic plume. This was measured following the explosive eruption of Eyjafjallajökull in 2010, where at the GAW site Puy de Dôme, France (1465 $\mathrm{m}$ above sea level), nucleation and secondary aerosol formation events within the volcanic plume were observed (Boulon et al., 2011). The site, however, was in the free troposphere and occurred in a plume which was ash rich. To date there is very limited evidence of the processes of particle nucleation and secondary aerosol formation in distal plumes from effusive eruptions.

The recent Holuhraun eruption within the Bárðarbunga volcanic system in Iceland (August 2014-February 2015) was the largest Icelandic eruption in terms of erupted magma and gas volume since the 1783-1784 CE Laki event, producing $1.6 \mathrm{~km}^{3}$ of lava and total $\mathrm{SO}_{2}$ emissions of $11 \pm 5 \mathrm{Mt}$ during a period of 6 months (Gíslason et al., 2015). It was almost purely effusive, hence producing negligible amounts of ash, but repeatedly causing severe air pollution events in populated areas of Iceland due to high gas and aerosol concentrations. The ground level concentration of $\mathrm{SO}_{2}$ exceeded the hourly health limit $\left(350 \mu \mathrm{g} \mathrm{m}^{-3}\right)$ over much of the country for periods of up to several weeks
(Gíslason et al., 2015) and there were complaints as far as Scandinavia of a foul smell, which has been attributed to sulfurous compounds from the fissure eruption using satellite data (Grahn et al., 2015). Exceedances in the hourly health limits were also observed for $\mathrm{SO}_{2}$ periodically in Northern Finland at surface observation sites, which were confirmed by satellite observations (Ialongo et al., 2015). In Europe, anthropogenic emissions of sulfur have been declining over the past few decades and hence lower concentrations are observed widely (Fowler et al., 2007). The 28 European Union member countries (EU-28) total annual emissions of sulfur oxides in 2010 and 2011 were $\sim 4.6 \mathrm{Mt}$ (http://www.eea.europa.eu/data-and-maps/daviz/ emission-trends-of-sulphur-oxides\#tab-chart_1) and therefore the Holuhraun volcanic eruption added more than twice the EU-28 annual sulfur emissions to the atmosphere in just 6 months (Schmidt et al., 2015). This eruption provided the unique opportunity in Europe to study the impact of a large point source $\mathrm{SO}_{2}$ emission.

This paper studies the volcanic impact on the UK atmosphere and focuses on one major incursion in September 2014 during the Holuhraun eruption and provides the first evidence of wide-scale effects, based on the measurements from the UK air quality monitoring networks which deliver data at both high (hourly) and low (monthly) temporal resolution. These observations provide information on the chemical composition of the distal plume, $\sim 1000 \mathrm{~km}$ downwind of Iceland. Because Icelandic air arrives at the UK on northerly trajectories, the background air is clean and there is little interference from anthropogenic emissions when the air arrives at the northern UK.

In 2014, hourly-resolution measurements of $\mathrm{SO}_{2}$ were made by the UK Automatic and Rural Monitoring Network (AURN, http://uk-air.defra.gov.uk/networks/ network-info?view=aurn) and by the two UK European Monitoring and Evaluation Program (EMEP) (Tørseth et al., 2012) atmospheric observatories (Harwell, SE England, UK, and Auchencorth Moss, SE Scotland, UK), which also form part of the ACTRIS Infrastructure Network (http://www.actris.eu/). Additional high-resolution physical PM mass and size distribution (refer to Sect. 2.2), as well as chemical composition measurements (refer to Sect. 2.1) at the two EMEP observatories are presented. In addition supplementary evidence of long-term perturbations in the UK background at a lower resolution during the volcanic event from the UK Acid Gas and Aerosol Network (AGANet) and Precipitation network (Precip-Net) are highlighted (refer to Sect. 2.3). 


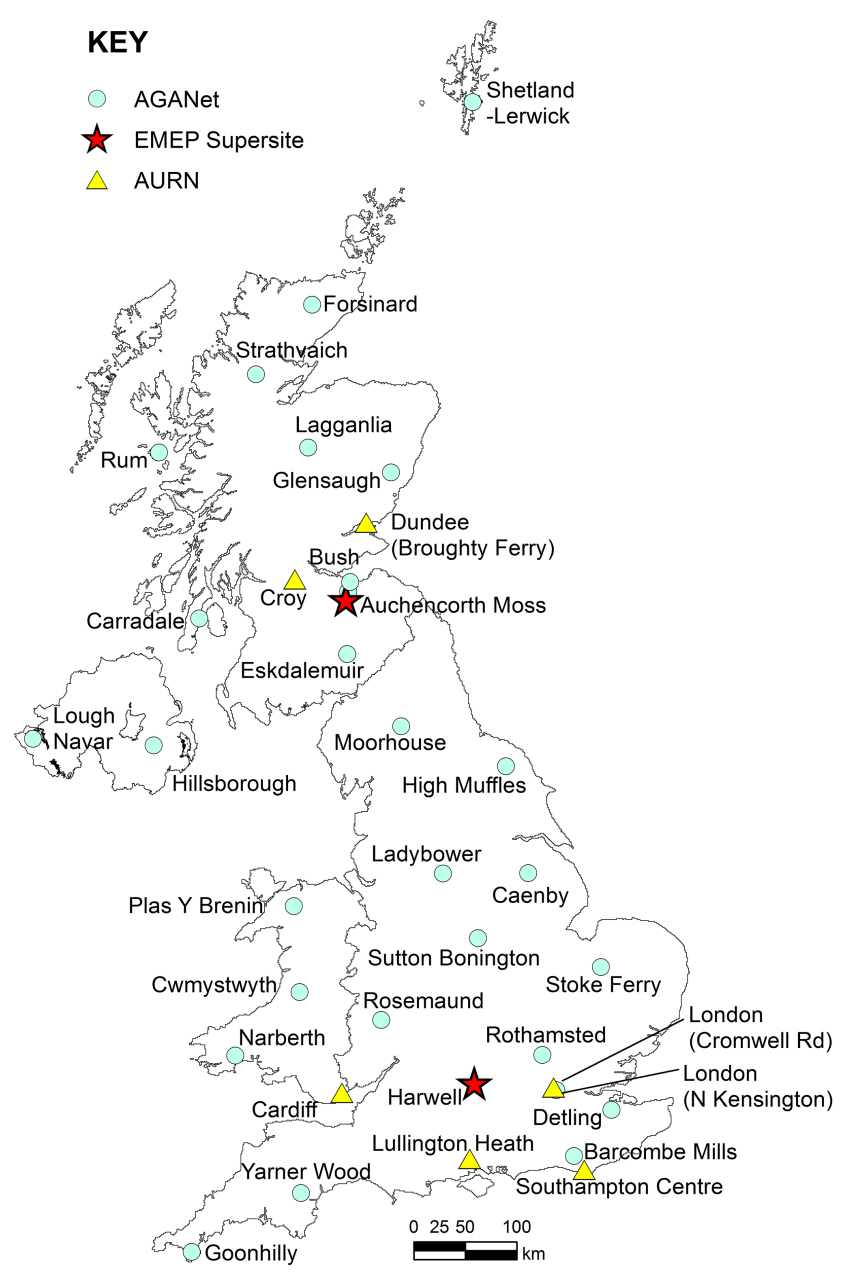

Figure 1. Map of $\mathrm{SO}_{2}$ monitoring sites in the UK used in this study. The AGANet sites provide monthly average concentrations, whilst the other sites report hourly values.

\section{Methods}

\subsection{Basics of the Measurement of Aerosols and Reactive Gases Analyser (MARGA) operation}

The MARGA (Metrohm Applikon B.V., NL) provides hourly-resolution measurements of water soluble inorganic aerosol speciation $\left(\mathrm{SO}_{4}^{2-}, \mathrm{Cl}^{-}, \mathrm{NO}_{3}^{-}, \mathrm{NH}_{4}^{+}, \mathrm{Na}^{+}, \mathrm{K}^{+}, \mathrm{Ca}^{2+}\right.$ and $\left.\mathrm{Mg}^{2+}\right)$ and gases $\left(\mathrm{SO}_{2}, \mathrm{HCl}, \mathrm{HNO}_{3}, \mathrm{HONO}\right.$ and $\left.\mathrm{NH}_{3}\right)$. At the two field sites Harwell and Auchencorth Moss (Fig. 1), the instruments are configured to have two sample boxes, one for $\mathrm{PM}_{10}$ and one for $\mathrm{PM}_{2.5}$. The instruments use wet rotating denuders (WRDs) (Wyers et al., 1993) and steam jet aerosol collectors (SJACs) (Khlystov et al., 1995) for sampling of gases and aerosols respectively. Analysis is carried out online by ion chromatography (both anion and cation) at an hourly resolution. A detailed description of the instrument and quality assurance/quality control (QA / QC) procedures used by both instruments is given in Twigg et al. (2015). There is one operational difference between the Auchencorth and Harwell instruments, where Auchencorth Moss uses preconcentration columns (Metrosep A PCC 1 HC ion chromatography (IC) preconcentration column $(2.29 \mathrm{~mL})$ for anions and a Metrosep C PCC1 HC IC preconcentration column $(3.21 \mathrm{~mL})$ for cations) on the IC to achieve a lower detection limit (DL) compared to the Harwell instrument which uses fixed loops $(250 \mu \mathrm{L}$ for anions and $480 \mu \mathrm{L}$ for cations) and therefore has an order of magnitude higher DL as described by Makkonen et al. (2012). Data from both MARGA instruments are available in the UK-Air (http://uk-air.defra.gov.uk/data/) and EBAS (http://ebas.nilu. no/default.aspx) databases.

\subsection{Scanning mobility particle sizer (SMPS)}

At both EMEP supersites SMPSs are installed which count the individual aerosol numbers within predefined size bins of aerosols. At Harwell, aerosol number size distributions measured in the range of 16.55 to $604.3 \mathrm{~nm}$ by the SMPS (Electrostatic classifier 3080, differential mobility analyser 3081 and condensation particle counter 3775; all TSI Inc.). The system sampled air at $4 \mathrm{~m}$ a.g.l. through a $\mathrm{PM}_{1}$ cyclone before entering the analyser via a drier, which ensured the relative humidity of the sample air was kept below $45 \%$. The aerosol sample flow rate was set to $0.3 \mathrm{~L} \mathrm{~min}^{-1}$ and the Classifier sheath flow was maintained at $3 \mathrm{~L} \mathrm{~min}^{-1}$; a detailed description of the method and setup employed at Harwell can be found in Beccaceci et al. (2013) and data are freely available through the UK-Air website.

At Auchencorth Moss aerosol size distributions in the range of 14-673 nm were set to be measured using the SMPS (Electrostatic classifier 3081, differential mobility analyser 3080 and condensation particle counter 3775; all TSI Inc.). Air was sampled at $2 \mathrm{~m}$ a.g.1. through a $\mathrm{PM}_{10}$ head and $\mathrm{PM}_{2.5}$ cyclone before entering the analyser via a drier which ensured the relative humidity of the sample air was kept below $45 \%$. The aerosol sample flow rate was set to $0.3 \mathrm{~L} \mathrm{~min}^{-1}$ and the classifier sheath flow was maintained at $3 \mathrm{~L} \mathrm{~min}^{-1}$ as set out in Wiedensohler et al. (2012). In October 2015, the Auchencorth Moss SMPS took part in an intercomparison organized by the EU Horizon 2020 ACTRIS 2 (aerosol, clouds and trace gases research infrastructure), held at the world aerosol calibration centre (TROPOS, Leipzig, Germany). During this exercise the classifier used at Auchencorth was found to have an offset and was starting a scan at $35 \mathrm{~nm}$ instead of $14 \mathrm{~nm}$, though it is unclear whether this may have slowly drifted over the 18 months since installation at the site. Therefore data presented from Auchencorth Moss are a qualitative indicator of an increase in ultrafine particles as the size distribution could not be verified. 


\subsection{AGANet DEnuder for Long-Term Atmospheric sampling (DELTA) and Precip-Net}

The DELTA, used in AGANet across the UK, is described by Sutton et al. (2001) are used to measure the spatial concentrations of both inorganic trace gases $\left(\mathrm{NH}_{3}, \mathrm{HNO}_{3}\right.$, $\mathrm{SO}_{2}$ and $\mathrm{HCl}$ ) and counterpart aerosols at a monthly resolution across the UK. The sampling system consists of a series of coated denuders (to capture gases) and filters (to capture the aerosol). Air is sampled at a flow rate of $0.2-$ $0.4 \mathrm{~L} \mathrm{~min}^{-1}$, with the sampling inlet at a height of $1.5 \mathrm{~m}$. The first pair of denuders $(15 \mathrm{~cm})$ after the inlet is coated with $\mathrm{K}_{2} \mathrm{CO}_{3} /$ glycerol to capture acidic gases. The next pair of denuders is coated with citric acid to capture gaseous $\mathrm{NH}_{3}$. A filter pack is situated at the end of the sampling train, containing two cellulose-coated filters. The first is impregnated with $\mathrm{K}_{2} \mathrm{CO}_{3}$ to capture and retain $\mathrm{NO}_{3}^{-}, \mathrm{SO}_{4}^{2-}, \mathrm{Cl}^{-}$and $\mathrm{Na}^{+}$, $\mathrm{Ca}^{2+}$ and $\mathrm{Mg}^{2+}$ aerosol. The second filter is impregnated with citric acid to capture $\mathrm{NH}_{4}^{+}$. Downstream of the sampling train is a gas meter to record the volume of air sampled and an air pump. A DELTA sampling train is exposed for 1 month and samplers are extracted with deionized water. Chemical analysis is performed by ion chromatography and flow injection analysis; further details of both the sampling method and analytical analysis are contained in Tang et al. (2009). The monitoring sites in AGANet are highlighted in Fig. 1. The wet deposition of pollutants in the UK is monitored within Precip-Net. Precip-Net uses bulk precipitation samplers at 39 non-urban sites with fortnightly sample collection. Samples are analysed for cations $\left(\mathrm{Na}^{+}, \mathrm{Ca}^{2+}, \mathrm{Mg}^{2+}\right.$, $\left.\mathrm{K}^{+}, \mathrm{NH}_{4}^{+}\right)$and anions $\left(\mathrm{PO}_{4}^{3-}, \mathrm{NO}_{3}^{-}, \mathrm{SO}_{4}^{2-}, \mathrm{Cl}^{-}\right)$using ion chromatography (further details of both the sample method and analysis can be found in Irwin et al., 2002). Data from both AGANet and Precip-Net are freely available from UKAir.

\subsection{GOME2 volcanic $\mathrm{SO}_{2}$ detection}

The GOME2 instrument on MetOp-B is a nadir-viewing $\mathrm{UV} /$ visible spectrometer with a spatial resolution of $40 \times 80 \mathrm{~km}^{2} . \mathrm{SO}_{2}$ column densities are retrieved using a differential optical absorption spectroscopy approach including a nonlinearity correction for $\mathrm{SO}_{2}$ saturation effects (Richter, 2009). Satellite UV/visible retrievals yield integrated vertical columns of absorbing species and usually do not provide information about the vertical distribution of a trace gas. As the sensitivity of the observations decreases towards the surface, an assumption has to be made in the retrieval on the vertical profile of the target species in order to apply appropriate weights called air mass factors. Here, the standard volcanic product from the University of Bremen is used (http:// www.iup.uni-bremen.de/doas/gome2_so2_alert.htm), which assumes a volcanic eruption profile with an $\mathrm{SO}_{2}$ peak at $10 \mathrm{~km}$ height. As no corrections are made for the effects of deviations from the assumed plume height of $10 \mathrm{~km}$, the data shown should be used as qualitative indicator only.

\subsection{EMEP4UK chemical transport model}

The EMEP4UK model rv4.3 (Vieno et al., 2016) is a chemical transport model which is the regional application of the EMEP MSC-W model (Simpson et al., 2012), used in this study to identify and investigate the spatial distribution of the volcano plume. The meteorological driver used in the EMEP4UK model is the Weather Research and Forecasting model (WRF) version 3.6. More details of the model description and setup of the model can be found in Vieno et al. (2014, 2010). The model domain includes all Europe and part of Russia with a horizontal resolution of $50 \mathrm{~km} \times 50 \mathrm{~km}$, with anthropogenic and biogenic emissions included based on the emissions the year 2012. The specific Icelandic volcano emissions in the run were set to $680 \mathrm{~kg} \mathrm{~s}^{-1}$ (Gíslason et al., 2015) from 31 August 2014 to the end of 2014, with the period of 19 to 24 September 2014 presented in this study. The emissions are injected into the model vertical column equally from the 1 to $3 \mathrm{~km}$.

\subsection{ISORROPIA thermodynamic model}

The chemical thermodynamics model, ISORROPIA II (Fountoukis and Nenes, 2007), is used to determine the theoretical chemical composition based on the gas / aerosol equilibrium partitioning of the inorganic species measured by the MARGA instrument at Auchencorth Moss. The model was run using as an input the bulk (i.e. gas + aerosol) concentration of all compounds (ammonium, nitrate, sulfate and chloride) measured by the MARGA (input in $\mu \mathrm{mol} \mathrm{m}^{-3}$ ) with measured temperature and relative humidity and operated in the metastable, forward reaction. The model was used to establish whether the observed gaseous concentrations could be explained solely by the thermodynamic equilibrium of the observed species, as there is very little evidence in the literature of direct acid displacement.

\subsection{Statistical analysis of AGANet data}

As well as high-temporal-resolution analysis (hourly measurements) of the volcanic plume, the monthly average $\mathrm{SO}_{2}$ from AGANet measurements (Sect. 2.3) were analysed to assess the impact of the fissure eruption on the background atmosphere across the UK. The plume was clearly observable in this data set. In order to understand the relative magnitude of the perturbation on a national scale for both air quality and sulfur deposition, a statistical treatment was thought to be appropriate against a background of decreasing anthropogenic emissions. Specifically the likelihood of a reoccurrence of the observed concentrations in the UK background was calculated as many AGANet sites show decreasing trends over time for $\mathrm{SO}_{2}$ and $\mathrm{SO}_{4}^{2-}$, reflecting decreases in emissions. This is observed for both the annual mean concentration and 
the annual maximum concentration. A high concentration superimposed on a downward concentration trend in a measurement series over a period appears to be a less unlikely observation at the end of the time period than at the beginning. Therefore the AGANet measurement data were adjusted to remove any underlying trends before further analysis to assess the unusualness of the September 2014 elevated $\mathrm{SO}_{2}$ concentrations. Theoretically exceedances over a threshold follow a Pareto distribution and the threshold was chosen by fitting an $85 \%$ quartile regression to this data set using a smoothing spline for each site individually (i.e. there was no assumption of a general trend). This methodology has previously been developed much further for application to case studies with substantially more data (Chavez-Demoulin and Davison, 2005; Northrop and Jonathan, 2011; Reich et al., 2011). The fitted Pareto distribution generates the probabilities of occurrence of the elevated concentrations - which in this case were associated with the volcanic plume. This is expressed in Table 1 as a return probability and return time, which is the statistical likelihood of a similar concentration to be observed again based on the long-term trend of $\mathrm{SO}_{2}$ over the 1999-2014 period at each site expressed in the resolution of the measurements.

\section{Results and discussion}

\subsection{Identification of a volcanic plume in the UK atmosphere}

During the Holuhraun eruption, the volcanic plume passed periodically over the UK, with a major event occurring between 21 and 23 September 2014. This plume was first detected at the UK supersite in Scotland at Auchencorth Moss at 12:00 (GMT), followed by Harwell in England at 15:00 (GMT) (Fig. 2). The plume moved across the UK (with the exception of parts of Northern Ireland) and AURN $\mathrm{SO}_{2}$ observations at selected sites are summarized in Fig. 2. Scotland (Dundee, Croy and Auchencorth) observed higher concentrations of $\mathrm{SO}_{2}$ compared to the rest of UK. The sites in southern Scotland (Auchencorth Moss and Croy), however, were only exposed to the main plume on 21 September whereas the event affected the rest of the UK intermittently for the next $72 \mathrm{~h}$ (Fig. 2). The peak $\mathrm{SO}_{2}$ concentration measured by the MARGA at Auchencorth was $66.8 \mu \mathrm{g} \mathrm{m}^{-3}$ (Fig. 2) compared with the annual average of $\mathrm{SO}_{2}$ of $0.14 \mu \mathrm{g} \mathrm{m}^{-3}$ in 2013 at the site. It has to be noted that the $\mathrm{SO}_{2}$ concentration at Auchencorth Moss was underestimated between 11:00 and 22:00 on 21 September 2014 because the standard instrument configuration was optimized for $<1 \mu \mathrm{g} \mathrm{m}^{-3}$ detection. The maximum reported $\mathrm{SO}_{2}$ concentration during the event at Harwell reported by the MARGA was lower, peaking at $45.7 \mu \mathrm{g} \mathrm{m}^{-3}$ (annual average concentration in 2013 was $0.46 \mu \mathrm{g} \mathrm{m}^{-3}$ ) and occurring on 22 September. Although $\mathrm{SO}_{2}$ concentrations were elevated in many parts of the UK, they were notably below the $24 \mathrm{~h}$ average air quality limit of $125 \mu \mathrm{g} \mathrm{m}^{-3}$ set under the EU Air Quality Framework Directive (Directive 2008/50/EC). The $\mathrm{SO}_{2}$ plume was also observed across Ireland, Netherlands, Belgium, Finland and Austria (TS-2 in the Supplement of Gíslason et al., 2015, and Ialongo et al., 2015) during different periods of the fissure eruption.

Supporting evidence that the ground-based measurements in September 2014 were picking up a volcanic signal is provided by the GOME2 instrument on the MetOp-B satellite, as it was able to track the $\mathrm{SO}_{2}$ plume from the Holuhraun eruption site to the UK (Fig. 3) on 20 and 21 September. While satellite observations only provide tropospheric columns of $\mathrm{SO}_{2}$ and not the concentrations at surface which are reported by the ground-based measurements, they do provide important information on the origin of enhanced $\mathrm{SO}_{2}$ values. As the sensitivity of satellite retrievals to surface $\mathrm{SO}_{2}$ is low, sulfur dioxide from surface pollution can rarely be detected over Europe. Volcanic plumes in contrast can readily be observed in the data as they usually extend to higher altitudes and contain much larger vertical columns of $\mathrm{SO}_{2}$. The fact that several Dobson units of $\mathrm{SO}_{2}$ are observed in GOME2 data on 20 and 21 September 2014 over the UK and that the $\mathrm{SO}_{2}$ plume originates from Iceland strongly indicates that the observed $\mathrm{SO}_{2}$ is of volcanic origin. It is therefore very probable that simultaneous $\mathrm{SO}_{2}$ enhancements measured at the surface are also linked to the volcanic emissions. Modelling of the plume by EMEP4UK further confirmed the volcanic origin and dispersion of the observed $\mathrm{SO}_{2}$ plumes both at Harwell and Auchencorth Moss (Fig. 4), as did back trajectories using the HYSPLIT model, which can be found in Figs. S1-S2 in the Supplement. To provide evidence that the EMEP4UK model was able to replicate the spatial distribution of the plume a comparison of the time series of observations to the model at both sites is given in the Supplement (Fig. S3). Though in general the EMEP4UK model does get the spatial distribution of the plume correct, there are a number of explanations why the model does not precisely replicate the plume compared to the measurements at the surface. The reasons include a number of input variables which would have impacted the distribution of the plume including injection height, daily emission rates at source and oxidation rate within the plume; in addition, the model output is $50 \mathrm{~km} \times 50 \mathrm{~km}$ resolution.

\subsection{Chemistry within the volcanic plume}

\subsubsection{Formation of sulfate aerosols}

Current understanding of volcanic emissions is that the major fraction of observed $\mathrm{SO}_{4}^{2-}$ is not directly emitted from the magma but is formed as secondary aerosol through oxidation of $\mathrm{SO}_{2}$ in the atmosphere (Mather et al., 2013), though there are some reports suggesting primary emissions are possible (Allen et al., 2002; Zelenski et al., 2015). As shown in 
Table 1. Statistical analysis of the UK AGANET sites $\mathrm{SO}_{2}$ (refer to Sect. 2.7 for the methods), where the return probability is the statistical likelihood of a similar concentration to be observed again based on the long-term trend of $\mathrm{SO}_{2}$ at each site. (Refer to Fig. 1 for site locations.)

\begin{tabular}{lrrrrr}
\hline Site & $\begin{array}{r}\text { September 2014 average } \\
\mathrm{SO}_{2}\left(\mathrm{\mu g} \mathrm{m}^{-3}\right)\end{array}$ & $\begin{array}{r}\text { Fitted 85\% } \\
\text { quartile }\end{array}$ & residual & $\begin{array}{r}\text { Return } \\
\text { probability }\end{array}$ & $\begin{array}{r}\text { Return period } \\
\text { (months) }\end{array}$ \\
\hline Yarner Wood & 3.48 & 0.40 & 3.08 & $3.11 \times 10^{-4}$ & 3218.5 \\
Rothamsted & 2.98 & 0.78 & 2.20 & $9.00 \times 10^{-3}$ & 111.1 \\
London Cromwell Road & 2.37 & 0.54 & 1.83 & $6.90 \times 10^{-3}$ & 144.9 \\
Ladybower & 2.29 & 1.34 & 0.95 & $3.22 \times 10^{-2}$ & 31.0 \\
Harwell & 2.28 & 0.82 & 1.46 & $6.73 \times 10^{-3}$ & 148.7 \\
Halladale & 2.11 & 1.03 & 1.08 & $5.60 \times 10^{-3}$ & 178.6 \\
Strathvaich & 2.09 & 0.28 & 1.81 & $2.40 \times 10^{-3}$ & 417.4 \\
Shetland & 2.04 & 1.02 & 1.02 & $6.20 \times 10^{-3}$ & 161.2 \\
Auchencorth Moss & 2.00 & 0.37 & 1.63 & $8.71 \times 10^{-3}$ & 114.8 \\
Glensaugh & 1.95 & 0.57 & 1.38 & $6.17 \times 10^{-3}$ & 162.0 \\
Stoke Ferry & 1.84 & 0.68 & 1.16 & $1.70 \times 10^{-2}$ & 58.8 \\
Sutton Bonnington & 1.70 & 1.11 & 0.59 & $7.11 \times 10^{-2}$ & 14.1 \\
Barcombe Mills & 1.68 & 0.74 & 0.94 & $8.98 \times 10^{-3}$ & 111.3 \\
High Muffles & 1.67 & 1.14 & 0.53 & $7.72 \times 10^{-2}$ & 12.9 \\
Lagganlia & 1.65 & 1.14 & 0.51 & $7.28 \times 10^{-3}$ & 137.4 \\
Eskdalemuir & 1.45 & 0.42 & 1.03 & $5.65 \times 10^{-3}$ & 177.1 \\
Bush Estate & 1.38 & 0.60 & 0.78 & $4.55 \times 10^{-2}$ & 22.0 \\
Moorhouse & 1.24 & 0.47 & 0.77 & $1.10 \times 10^{-2}$ & 90.6 \\
Narberth & 1.20 & 1.08 & 0.12 & $8.69 \times 10^{-2}$ & 11.5 \\
Rosemaund & 1.15 & 0.51 & 0.64 & $1.19 \times 10^{-2}$ & 84.0 \\
Cwmystwyth & 1.10 & 0.49 & 0.61 & $2.11 \times 10^{-2}$ & 47.3 \\
Plas Y Brenin & 1.08 & 1.08 & 0.00 & $1.41 \times 10^{-1}$ & 7.1 \\
Caenby & 0.98 & 0.98 & 0.00 & $1.44 \times 10^{-1}$ & 6.9 \\
Edinburgh St Leonards & 0.61 & 1.32 & -0.71 & $4.06 \times 10^{-1}$ & 2.5 \\
Hillsborough & 0.61 & 0.61 & 0.00 & $1.37 \times 10^{-1}$ & 7.3 \\
Detling & 0.58 & 1.01 & -0.43 & $6.79 \times 10^{-1}$ & 1.5 \\
Goonhilly & 0.47 & 0.49 & -0.02 & $1.36 \times 10^{-1}$ & 7.4 \\
Lough Navar & 0.39 & 0.39 & 0.00 & $1.75 \times 10^{-1}$ & 5.7 \\
Rum & 0.07 & 0.21 & -0.14 & $9.08 \times 10^{-1}$ & 1.1 \\
Carradale & nd & & & & \\
\hline & & & & &
\end{tabular}

Fig. 2, both atmospheric observatories in the UK detected an increase in $\mathrm{SO}_{4}^{2-}$ during the volcanic plume event in September 2014. $\mathrm{SO}_{2}$ oxidation with the hydroxyl radical in the troposphere can be slow, taking up to 2 weeks under some conditions, though if $\mathrm{SO}_{2}$ is taken up onto particles, oxidation rates are much faster, resulting in a lifetime of days or hours in clouds as $\mathrm{SO}_{2}$ (von Glasow et al., 2009). In order to understand the oxidation of an $\mathrm{SO}_{2}$ plume, Satsumabayashi et al. (2004) defined a sulfur conversion ratio $\left(F_{\mathrm{S}}\right)$ as $F_{\mathrm{s}}=$ $\left[\mathrm{PM}_{2.5} \mathrm{SO}_{4}^{2-}\right] /\left(\left[\mathrm{SO}_{2}\right]+\left[\mathrm{PM}_{2.5} \mathrm{SO}_{4}^{2-}\right]\right)$ (all concentrations

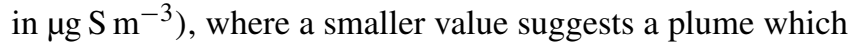
has not undergone considerable atmospheric processing. The UK observatory data sets showed $F_{\mathrm{S}}$ decreasing from $\sim 1$ (all $\mathrm{S}$ in the form of $\mathrm{SO}_{4}^{2-}$ ) to $F_{\mathrm{S}} \sim 0.2$, (Fig. 5) during the event, implying that $\mathrm{SO}_{2}$ oxidation had not had sufficient residence time (and oxidant exposure) to be complete. As the plume passed over the sites, the presence of ultrafine particles also became pronounced compared to the background atmosphere in the previous $24 \mathrm{~h}$ (Fig. 5). The volcano plume event was characterized by the high particle number density at low diameters, increasing in diameter with time (initiating at $\sim 12: 00$ GMT on the 21st, Fig. 5). The feature of increasing particle numbers, or "banana" shape in Fig. 5, starting with high particle numbers at the detection limit of the SMPS is characteristic of particle nucleation and growth. However, as it is not a Lagrangian measurement and the nucleation does not represent a widespread regional phenomenon (as it probably does, for example, in the nucleation studies conducted in the Boreal environment; Kulmala et al., 1998), the evolution of the size distribution with time needs to be interpreted with caution: only if trajectories and wind speed do not change with time can the temporal change at the fixed site be translated into the temporal change within the plume. It is possible that a population of ultrafine $\mathrm{H}_{2} \mathrm{SO}_{4}$ particles were emitted or formed at source; however, it is highly unlikely due to the transport time (refer to the HYSPLIT back tra- 

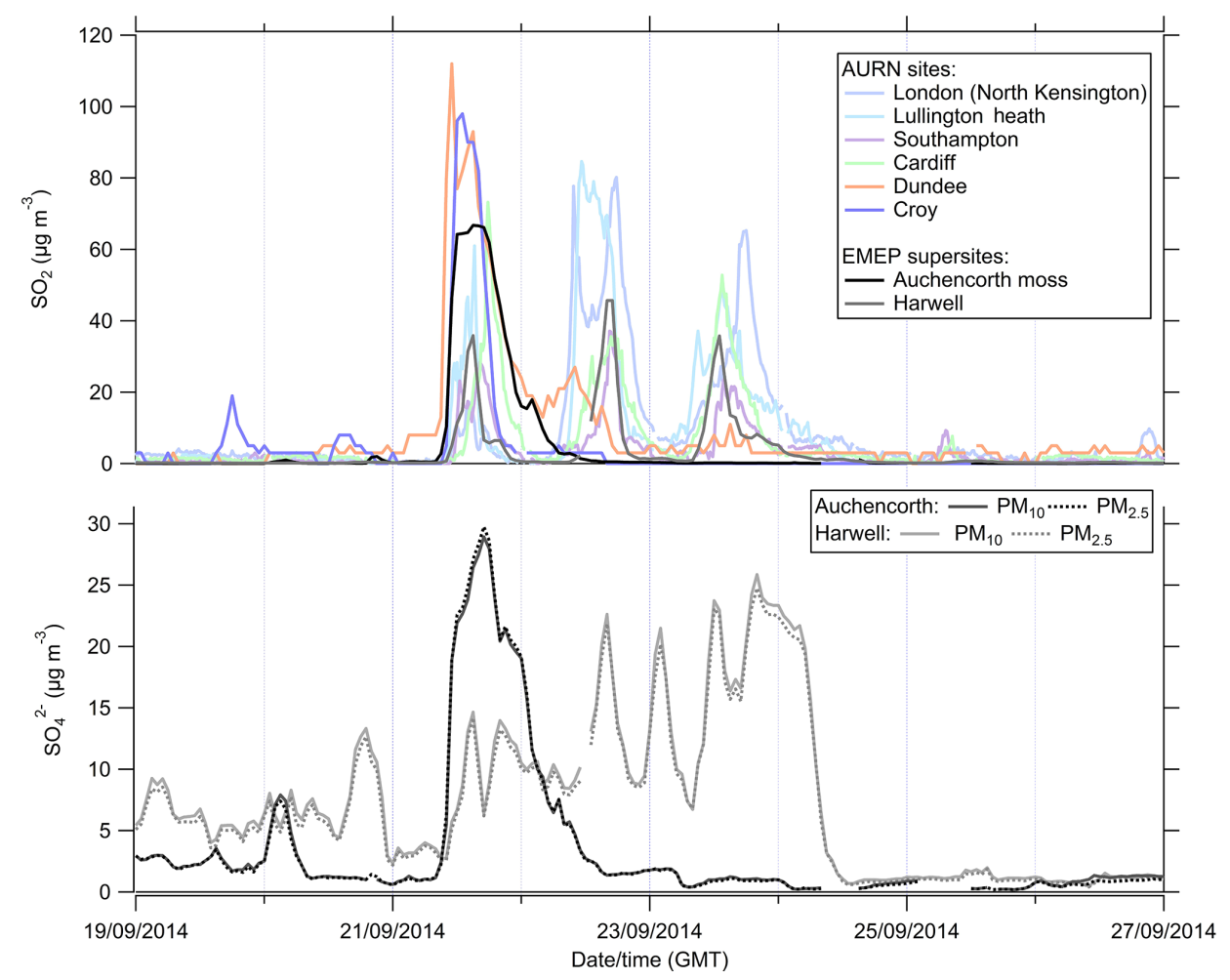

Figure 2. Time series of $\mathrm{SO}_{2}$ hourly measurements made at six AURN sites in the UK and the two UK EMEP supersite measurements of $\mathrm{SO}_{2}$ and $\mathrm{PM}_{10 / 2.5} \mathrm{SO}_{4}^{2-}$. (Note: $\mathrm{SO}_{2}$ at Auchencorth Moss is underestimated between 11:00 and 22:00 (GMT) on 21 September 2014.)
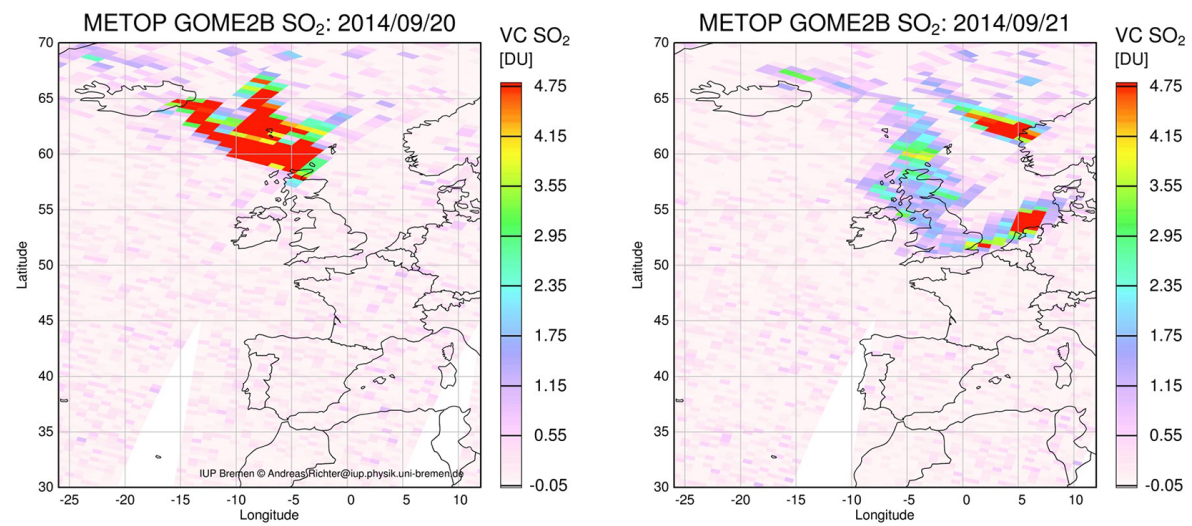

Figure 3. Observation of the volcanic plume from Iceland to and across the UK by the GOME2B satellite instrument, taken at the satellite overpass around 09:30 local time. GOME2B measures $\mathrm{SO}_{2}$ column density, where $\mathrm{VC}$ is the vertical column, which is the $\mathrm{SO}_{2}$ concentration integrated vertically to provide a column density per unit surface area. $\mathrm{SO}_{2}$ columns are given in Dobson units (DU); the thickness the $\mathrm{SO} 2$ layer would have at standard temperature and pressure is in units of hundredths of a millimetre.

jectories found in Fig. S1) that aerosol would have remained in the ultrafine fraction observed as they would have undergone further growth by coagulation and further condensation of condensable vapours. It is much more likely that sulfuric acid was formed during transport through oxidation of the high concentrations of $\mathrm{SO}_{2}$ by the $\mathrm{OH}$ radical, the production of which is linked to solar radiation. It is hypothesized that with increasing time after sunrise, the measurements at Auchencorth reflect particles whose nucleation was initiated further and further away from Auchencorth and had increasing time to grow during transport. The SMPS at Harwell also recorded similar events as the plume passed over. This is the first evidence of boundary layer surface-level particle growth observations in a distal volcanic plume for the UK 


\section{Daily $\mathrm{SO}_{2} \mu \mathrm{gm}^{-3}$}
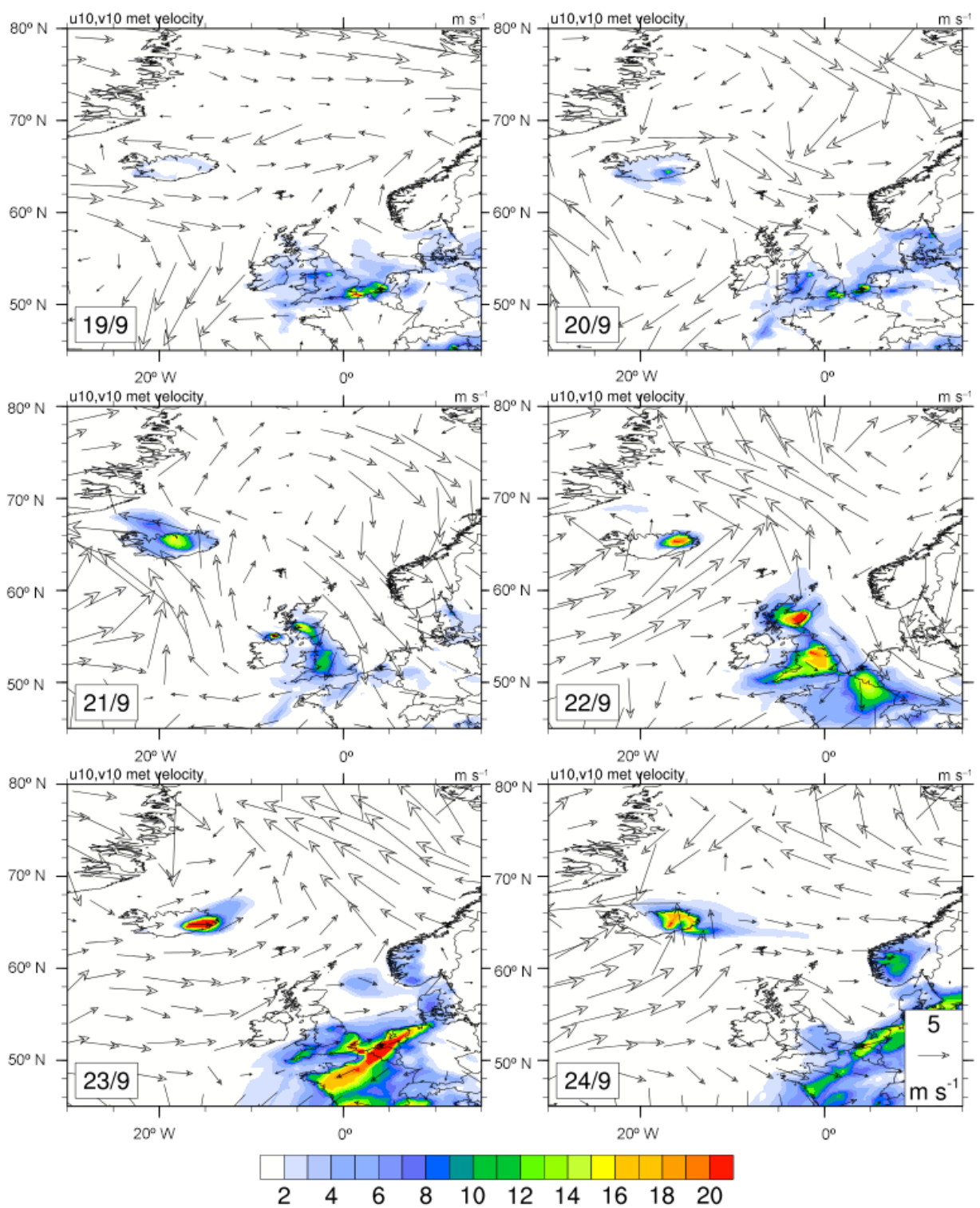

Figure 4. Daily average surface concentration $\left(\mu \mathrm{g} \mathrm{m}^{-3}\right)$ of $\mathrm{SO}_{2}$ from 19 to 24 September 2014, calculated by the EMEP4UK model and the 12:00 GMT of each day's wind vector.

and complements observations from the 2010, which is the only previous report of nucleation and secondary aerosol formation event reported for a distal plume during the explosive, ash-rich plume (Eyjafjallajökull in 2010) at an elevated freetropospheric atmospheric station in Europe (Puy de Dôme observatory, France) (Boulon et al., 2011). At that station, the free-tropospheric conditions and size range of measurements allowed the clear interpretation of particle nucleation. Though nucleation is thought to occur in the free troposphere where there is a low particle surface area there is increasing evidence in the literature of nucleation events measured at the surface in polluted environments: Hamed et al. (2007) observed nucleation events in the Po Valley, Italy, and Kulmala et al. (2005) in New Delhi. In addition, we cannot rule out that other compounds are taking part in the nucleation process and aerosol growth observed. Furthermore, in addition to the particle population changes observed, the measurement indicates that there was an air quality impact from particulates during the 2014 eruption in addition to the $\mathrm{SO}_{2}$ air quality impacts discussed in the recent study of Schmidt et al. (2015). 

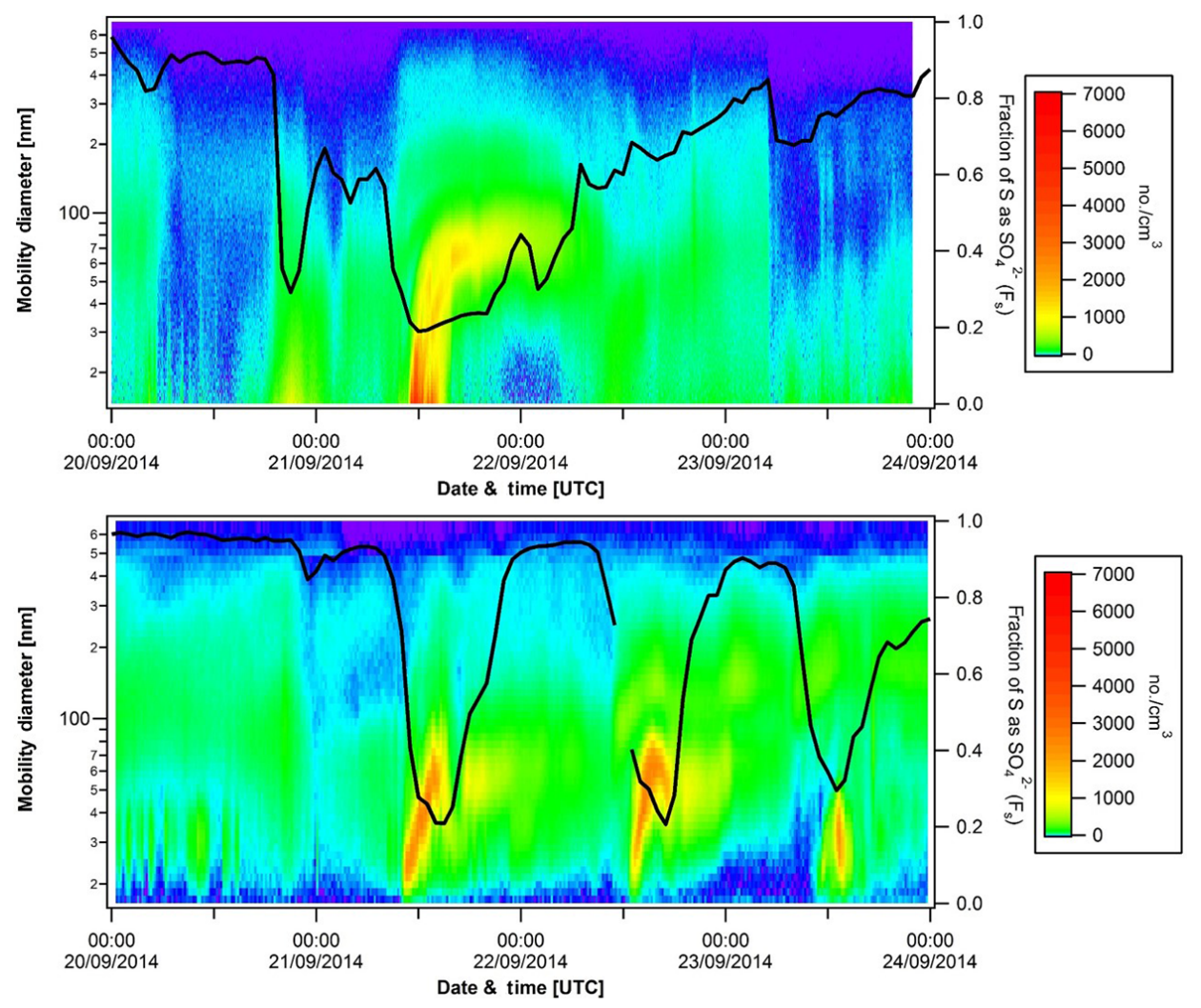

Figure 5. Particle number concentration at Auchencorth Moss (top panel) and Harwell (bottom panel) (refer to Fig. 1 for map) during the September 2014 volcanic plume event. Right-hand $y$ axis is the $F_{\mathrm{S}}$ ratio (black line) measured by the MARGA for the same period, where lower $F_{\mathrm{S}}$ indicates "younger" $\mathrm{SO}_{4}^{2-}$. (Note: there are uncertainties regarding the size calibration of the instrument (see text), but the CPC was working correctly. The panel should therefore be regarded a qualitative indicator of an increase in the ultrafine particulate matter during the volcanic plume.)

\subsubsection{Modification of the chemical composition within a volcanic plume}

The chemical composition of $\mathrm{PM}_{2.5}$ and the gas concentrations observed during the event at Auchencorth are summarized in Fig. 6. It is clear that the aerosol was dominated by $\mathrm{SO}_{4}^{2-}$. Whilst the aerosol at this site is normally basic, with free ammonia $\left(\mathrm{NH}_{3}\right)$ available based on ion balance studies (Twigg et al., 2015), during the plume event there is evidence that the aerosol turned acidic. The aerosol $\mathrm{pH}$ was confirmed using the results of $\left[\mathrm{H}^{+}\right]$calculated from ISORROPIA-II model to calculate $\mathrm{pH}$. During the plume event it was found that the $\mathrm{pH}$ dropped from $\mathrm{pH} 7.97$ at 09:00 GMT on 21 September 2014 to $\mathrm{pH} 3.80$ at 15:00 on 21 September 2014.

During the event the measurements at the background site clearly showed that there was an increase not only in the sulfur species but also in $\mathrm{HCl}$ gas and a variety of other chemical species in both gas and aerosol phase (Fig. 6). $\mathrm{HCl}$ peaked at $1.21 \mu \mathrm{g} \mathrm{m}^{-3}$ during the event compared with an annual average of $0.12 \mu \mathrm{g} \mathrm{m}^{-3}$ in 2013. As discussed in Aiuppa (2009), Pyle and Mather (2009) and summarized in Witham et al. (2015) and the literature cited therein, primary emissions of $\mathrm{HCl}$ from volcanoes can vary enormously depending on the magma type and the particular eruption characteristics. The near-source measurements of the gas composition from the Holuhraun eruption indicated that the gas phase in the plume was proportionally very low in halogen content, with a molar $\mathrm{HCl} / \mathrm{SO}_{2}$ ratio of $<1 \%$ (Burton et al., 2015). It is unlikely that $\mathrm{HCl}$ would persist longer in a plume than $\mathrm{SO}_{2}$ given the high solubility of $\mathrm{HCl}$ and comparably low reactivity of $\mathrm{SO}_{2}$. However, given that the $\mathrm{SO}_{4}^{2-}$ aerosol is highly acidic, the $\mathrm{HCl}$ would need to be scavenged onto other non-sulfate aerosol or into cloud droplets. Hence the elevated $\mathrm{HCl}$ observed in the plume event is due to either transport of primary $\mathrm{HCl}$ or displacement of $\mathrm{HCl}$ from background sea salt aerosol or a combination of the two. It is hypothesized that the most likely explanation for the observation of $\mathrm{HCl}$ coinciding with the plume is the oxidation of $\mathrm{SO}_{2}$ to sulfuric acid which then displaced $\mathrm{Cl}^{-}$in pre-existing sea salt aerosol $(\mathrm{NaCl})$ in the air mass. The thermodynamic model ISORROPIA-II (Fountoukis and Nenes, 2007) was used to calculate the theoretical partitioning between the gas and aerosol phase. The model clearly reproduces the $\mathrm{HCl}$ peak, 


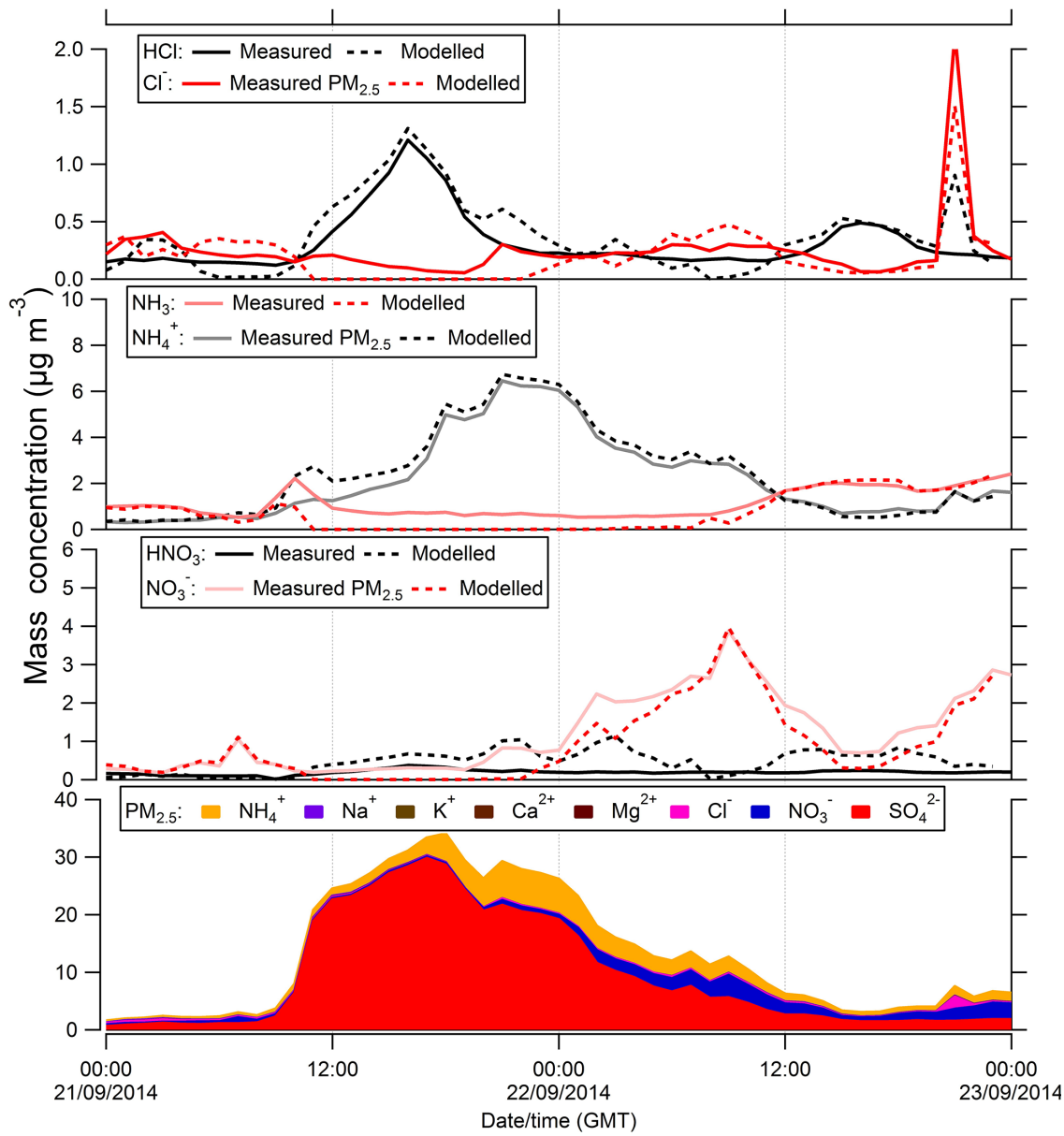

Figure 6. Top three panels: thermodynamic partitioning of gas and aerosol modelled by ISORROPIA-II compared with the measured concentrations at Auchencorth Moss. The bottom panel shows a stacked representation of the chemical composition of PM 2.5 at Auchencorth Moss as resolved by the MARGA instrument.

which is attributed to the displacement of $\mathrm{Cl}^{-}$from sea salt (Fig. 6). Further evidence of acid displacement was found at Auchencorth Moss when the ratio of $\mathrm{Na}^{+}$and $\mathrm{Cl}^{-}$was compared to the known ratio of sea water, where a large relative depletion of aerosol $\mathrm{Cl}^{-}$was found during elevated $\mathrm{SO}_{4}^{2-}$, represented by a change in colour of the markers in Fig. 7. This is not the first time the site has observed acid displacement; Twigg et al. (2015) observed the site to be rich in sea salt due to its proximity to the sea, with $35 \%$ of the annual average of the inorganic composition of $\mathrm{PM}_{2.5}$ attributed to sea salt. During high nitrate $\left(\mathrm{NO}_{3}^{-}\right)$episodes it was observed on occasion that this coincided with an apparent depletion of $\mathrm{Cl}^{-}$from sea salt, which was attributed to the displacement of $\mathrm{Cl}^{-}$by $\mathrm{HNO}_{3}$. Roberts et al. (2009) have previously modelled the likely perturbations within a volcano plume upon mixing with background air, which found that both ozone and $\mathrm{NO}_{x}$ were perturbed with bromine chemistry as the key driver. In order understand the net impact of this eruption on the chemical perturbation of background sea salt aerosol and the production of $\mathrm{HCl}$ in the gas phase, there would need to be a full chemical transport model which includes both chloride and bromine chemistry, which is beyond the scope of this paper. It is, however, noted that between 09:00 (GMT) on 21 September and 03:00 (GMT) on 22 September the $\mathrm{Na}^{+}$ was known to be underestimated, attributed to acidic composition of the aerosol resulting in a reduction in the performance of the cation column (concentration of the $\mathrm{Li}^{+}$internal standard decreased). Whilst correction based on the $\mathrm{Li}^{+}$ standard is possible, this assumes that the retention was similarly depressed for all cations. The data therefore have been flagged as invalid during the QA / QC procedures of data submission to UK-Air and EMEP but have been presented here as it is thought to be useful data for research purposes. As such the depletion of $\mathrm{Cl}^{-}$is thought to be even greater than that demonstrated in Fig. 7.

It is surprising that both acid displacement and nucleation events would be observed in parallel, as one process would be expected to be favoured over the other, depending on the aerosol surface area. Instead it is hypothesized that though both events are observed at the same time, it does not nec- 


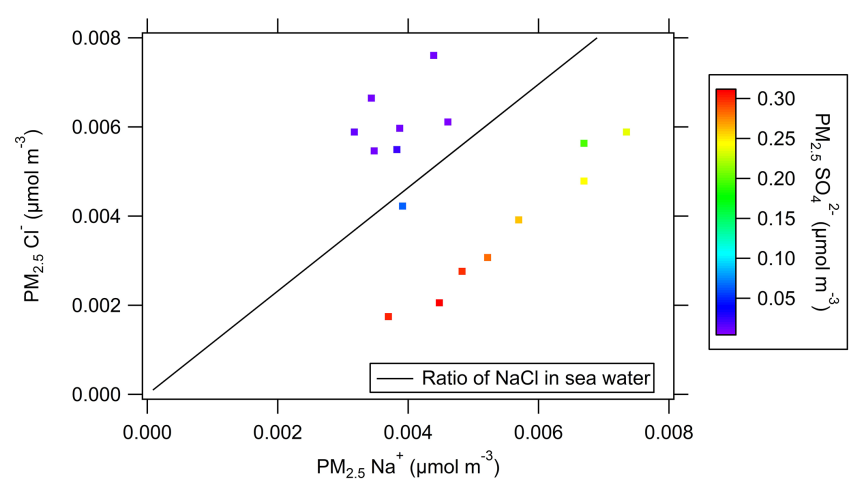

Figure 7. Evidence of acid displacement in sea salt $\left(\mathrm{PM}_{2.5}\right)$ on 21 September 2014 from 00:00 to 18:00 (GMT) at Auchencorth Moss where the solid line is the known ratio of $\mathrm{NaCl}$ in sea water (Seinfeld and Pandis, 2006).

essarily mean that they occur at the same time and at the same location. For the displacement reaction to occur, the sea spray aerosol needs to mix with the volcanic plume from aloft. It is feasible that this mixing generates "pockets of air" that are dominated by the volcanically influenced air (where nucleation is favoured) and others which have efficiently mixed with the sea salt (where heterogeneous chemistry is favoured). Through continued mixing and through the long-term integration of the measurement, both would be reported at the same time. Similarly, the conditions that favour one process over the other may vary along the trajectory between Iceland and the UK.

\subsection{Long-term perturbation of the UK atmosphere}

The relative importance of the volcanic plume over the 4 months on the UK surface composition and the wider region with respect to air quality and acid deposition can only be assessed with measurements over a wider geographic region. The low-temporal-resolution (monthly) measurements of gas and aerosol composition from AGANet at 30 sites (Fig. 1) provided a clear signal of the impact across the UK in particular for $\mathrm{SO}_{2}$ (Fig. 8). The national average concentration of $\mathrm{SO}_{2}$ from this network for September 2014 was about a factor of 6 larger than in the preceding month. Remote sites such as Strathvaich Dam in northern Scotland (Fig. 8: middle panel), which typically experience very little anthropogenic air pollution, experienced the highest monthly $\mathrm{SO}_{2}$ concentration on record (network operational since 1999), with September and October concentrations an order of magnitude higher than the long-term average $\left(2 \mu \mathrm{g} \mathrm{m}^{-3} \mathrm{cf}\right.$. $0.2 \mu \mathrm{g} \mathrm{m}^{-3}$ ). Similarly Yarner Wood in the south-west of England experienced the highest concentrations on record for the site and, even taking into account the underlying decreasing trend in $\mathrm{SO}_{2}$ concentrations, return probabilities were as low as $3 \times 10^{-4}$ (Table 1 , refer to Sect. 2.7 for statistical methods). At sites which are much more anthropogeni- cally influenced, though the plume is clearly observable, the $\mathrm{SO}_{2}$ concentration is unremarkable with return probabilities of $>1 \times 10^{-1}$ (e.g. Detling). A few sites on the western side of the UK were not in the pathway of the plume and therefore no elevated concentrations were observed, e.g. Rum. When assessing the wet deposition from Precip-Net, it was seen that many sites across the UK did experience elevated $\mathrm{SO}_{4}^{2-}$ concentrations in rain in September and October 2014 (Fig. 9, upper panel). Again, at particular sites in northern Scotland and South West England elevated concentrations were observed, whereas in Northern Ireland and parts of Wales no increase in $\mathrm{SO}_{4}^{2-}$ concentrations was evident. It has to be noted, however, that there was exceptionally low rainfall during September 2014 across the UK, with the month being the driest on record for the UK, based on a series from 1910 (which also equalled the fifth driest in the England and Wales in the precipitation series from 1766) (Parry et al., 2014). The majority of the western UK received less than $20 \%$ of the long-term average rainfall; hence the amount of sulfur deposited by wet deposition during this period was not important to the UK annual sulfur deposition budget and hence the environmental impact through acid deposition will have been minimal (Fig. 9). It therefore has to be noted that the reported high $\mathrm{SO}_{4}^{2-}$ could be the result of lack of dilution due to low precipitation and cannot be directly attributed to the volcanic plume.

\section{Conclusions}

The Holuhraun eruption perturbed the UK atmospheric composition periodically during the latter part of 2014. Elevated $\mathrm{SO}_{2}$ was observed by the networks at both high and low resolution. These observations complement the study by Schmidt et al. (2015), who reported similar observations for $\mathrm{SO}_{2}$ across Europe for the same period. This study, however, provides further details of the chemistry within the volcanic plume which are not addressed by Schmidt et al. (2015). In this study high $\mathrm{SO}_{2}$ concentrations were demonstrated to have resulted in an increase in tropospheric $\mathrm{HCl}$ due to the acid displacement of $\mathrm{Cl}^{-}$from sea salt at the EMEP supersite Auchencorth Moss. Elevated particulate $\mathrm{SO}_{4}^{-2}$ and particle size distributions from the two EMEP supersites provide observational evidence for new particle formation and growth was occurring as the plume passed over the UK. Future work now needs to be done to investigate the direct and indirect effects of the perturbation of chemistry, specifically with regards to human health and crop yields.

The analysis also provides evidence to support the recent modelling work undertaken which concluded that volcano eruptions in Iceland will intermittently affect the UK (Witham et al., 2015) both spatially and temporally during an eruption, primarily driven by meteorology. There is a significant difference in effects on both human health and ecosystem effects between acidic and non-acid aerosol and this 


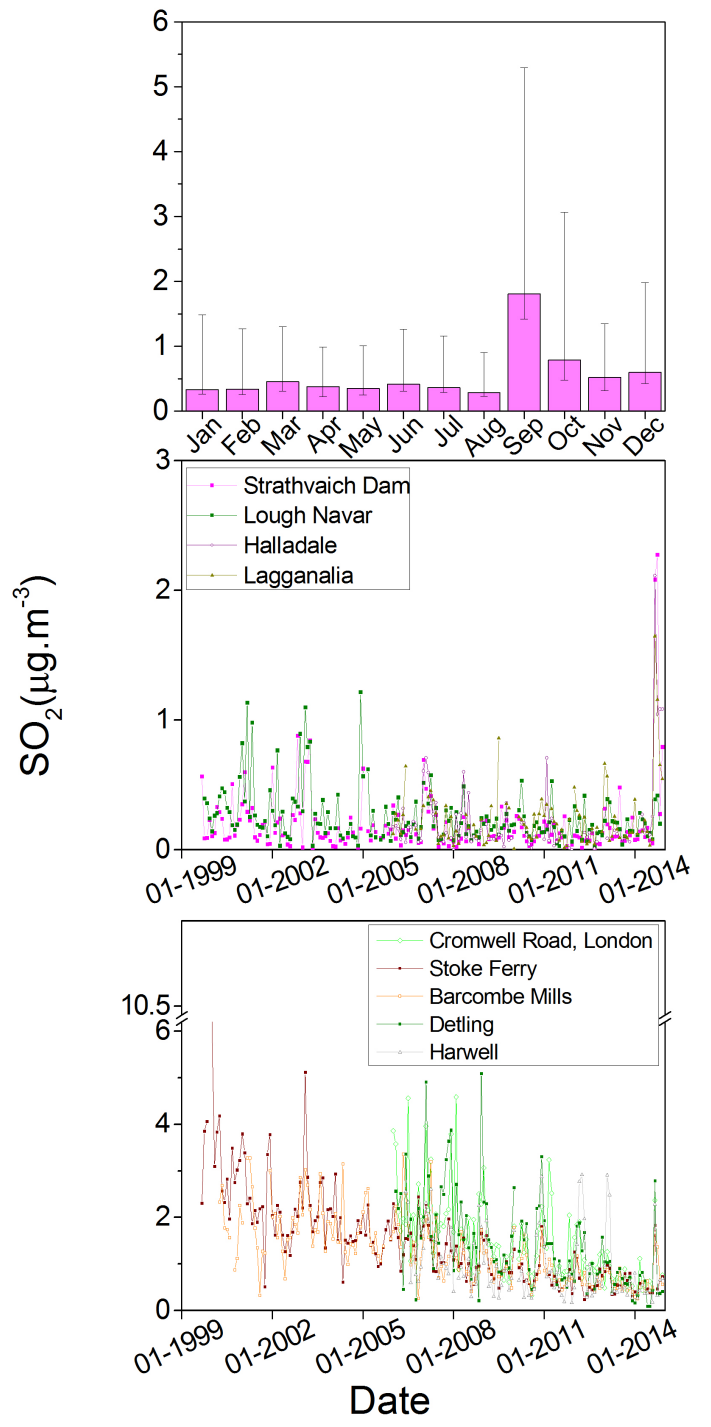

Figure 8. UK Defra Acid Gas and Aerosol Network monthly $\mathrm{SO}_{2}$. Top panel: 2014 monthly network average $\mathrm{SO}_{2}$ concentration (30 sites, whiskers maximum and minimum values); middle panel: five remote sites in the network; bottom panel: five sites in southern England (Refer to Fig. 1 map for location of sites).

study presents the first evidence that volcanic aerosol reaching the UK can be acidic, but this will be highly dependent on the mixing of the plume with the background atmosphere. There are also further impacts which have not yet been fully assessed, for example the net effect on climate (Gauci et al., 2008; Gettelman et al., 2015) and ecosystem function.

The study has highlighted that even though anthropogenic $\mathrm{SO}_{2}$ concentrations have dramatically decreased in the UK over the last 30 years, there is still a need to maintain the network of analysers as it is not only confirms recovery but also provides a useful tool to track the progression and impact of volcanic plumes and other pollution events. High-resolution chemical composition of aerosol is essential for the identifi-

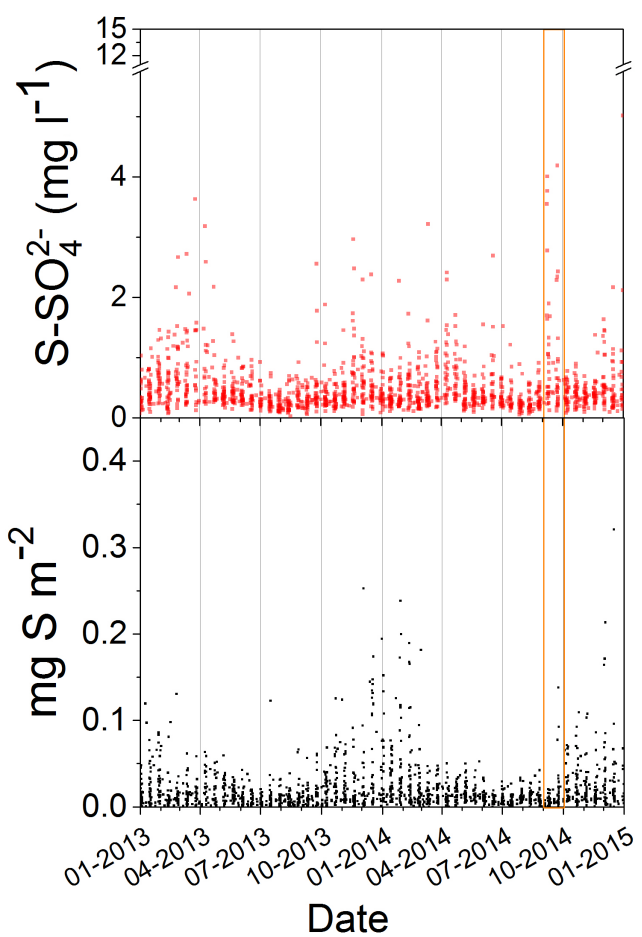

Figure 9. UK Precip-Net data: all fortnightly site data for 2013 and 2014. Upper panel: $\mathrm{S}_{-} \mathrm{SO}_{4}^{2-}$ concentrations; lower panel: sulfur deposition $\left(\mathrm{mg} \mathrm{S} \mathrm{m}^{-2}\right)$. Note fortnightly data with data plotted using the start date of the measurement period. (Data downloaded from UK-Air on 25 June 2015 and 2 February 2016.) The orange box highlights the measurements in September 2014.

cation of the origin of aerosol events observed concurrently with $\mathrm{SO}_{2}$ plumes and to understand the atmospheric chemistry. This paper presents the first detailed observations of chemistry within a distal volcano plume at the surface in the UK. This data set is unique and can be used by modellers to test long-term impacts of volcanic eruptions and the evolution of the plume chemistry.

While the 2014-2015 eruption in Holuhraun system was the largest eruption in Europe in over 200 years, there is a potential for even larger events. For example, the 1783-1784 Laki eruption was over 10 times larger in terms of erupted magma and gas volume. An event of this magnitude would cause significant and widespread pollution over Europe and even cause excess mortality (Schmidt et al., 2011). Though some work has been done on a limited data set of the European air quality networks by Schmidt et al. (2015) and Gíslason et al. (2015), a further study is required of the data from across the European compliance networks, as well as the EMEP and ACTRIS networks to integrate both particle characterization and gas chemical composition. This would allow the Holuhraun event to be fully characterized and quantified. 


\section{Data availability}

Data are available from UK-Air (https://uk-air.defra.gov.uk/ data/data_selector) for the Precip-Net, AGANet sites, the MARGA and the Harwell SMPS. MARGA data can also be found on the EBAS (http://ebas.nilu.no/) database. Sulfur dioxide data from Croy and Dundee were obtained from the Air Quality in Scotland Database (http://www. scottishairquality.co.uk/data/data-selector). The GOME2B data are a standard volcanic product from the University of Bremen which can be found at http://www.iup. uni-bremen.de/doas/gome2_so2_alert.htm. The EMEP4UK data and SMPS (Auchencorth Moss) are available from the authors on request.

\section{The Supplement related to this article is available online at doi:10.5194/acp-16-11415-2016-supplement.}

Acknowledgements. The authors would like to thank Susan Loughlin at the British Geological Survey for her encouragement and useful discussion on this work. We would also like to thank the late Roland Von Glasow for early discussions on the data presented here and acknowledge his great contribution to the study of halogens in the troposphere. The authors would like to acknowledge the following for the funding of the UK measurement networks, the UK Department for Environment, Food and Rural Affairs (Defra) and the devolved administrations, through the operation and management of the EMEP supersite, the UK Eutrophying and Acidifying Atmospheric Pollutants (UKEAP) project (AQ0647), the UK particle number and concentrations network, the UK Automatic Urban and Rural Network, as well as FP7 ACTRIS and Horizon 2020 ACTRIS-2. E. Ilyinskaya's work was funded by NERC urgency grant NE/M021130/1 and the European Community under the FP7 grant agreement no. 308377 (Project FUTUREVOLC).

Edited by: J. Quaas

Reviewed by: two anonymous referees

\section{References}

Aiuppa, A.: Degassing of halogens from basaltic volcanism: Insights from volcanic gas observations, Chem. Geol., 263, 99109, doi:10.1016/j.chemgeo.2008.08.022, 2009.

Aiuppa, A., Franco, A., von Glasow, R., Allen, A. G., D'Alessandro, W., Mather, T. A., Pyle, D. M., and Valenza, M.: The tropospheric processing of acidic gases and hydrogen sulphide in volcanic gas plumes as inferred from field and model investigations, Atmos. Chem. Phys., 7, 1441-1450, doi:10.5194/acp-7-1441-2007, 2007.

Aiuppa, A., Baker, D. R., and Webster, J. D.: Halogens in volcanic systems, Chem. Geol., 263, 1-18, doi:10.1016/j.chemgeo.2008.10.005, 2009.
Allen, A. G., Oppenheimer, C., Ferm, M., Baxter, P. J., Horrocks, L. A., Galle, B., McGonigle, A. J. S., and Duffell, H. J.: Primary sulfate aerosol and associated emissions from Masaya Volcano, Nicaragua, J. Geophys. Res.-Atmos., 107, 4682, doi:10.1029/2002jd002120, 2002.

Beccaceci, S., McGhee, E. A., Robins, C., Tompkins, J. T., Quincey, P. G., Brown, R. J. C., Butterfield, D. M., Green, D. C., Tremper, A., Priestman, M., Font Font, A., and Jones, A. M.: NPL report AS 93: Airborne Particulate Concentrations and Numbers in the United Kingdom (phase 3) - Annual report 2013, 2013.

Bobrowski, N., Honninger, G., Galle, B., and Platt, U.: Detection of bromine monoxide in a volcanic plume, Nature, 423, 273-276, 2003.

Bobrowski, N., von Glasow, R., Aiuppa, A., Inguaggiato, S., Louban, I., Ibrahim, O. W., and Platt, U.: Reactive halogen chemistry in volcanic plumes, J. Geophys. Res.-Atmos., 112, D06311, doi:10.1029/2006jd007206, 2007.

Boulon, J., Sellegri, K., Hervo, M., and Laj, P.: Observations of nucleation of new particles in a volcanic plume, Proc. Natl. Acad. Sci. USA, 108, 12223-12226, doi:10.1073/pnas.1104923108, 2011.

Burton, M., Ilyinskaya, E., La Spina, A., Salerno, G., Bergsson, B., Donovan, A., Barsotti, S., and Pfeffer, M.: Contrasting gas compositions and fluxes produced by the Holuhraun 2014/2015 eruption and the Fimmvörðuháls 2010 eruption, Iceland, Geophys. Res. Abstr., 17, EGU2015-15899, EGU General Assembly, Vienna, Austria, 2015.

Burton, M. R., Oppenheimer, C., Horrocks, L. A., and Francis, P. W.: Diurnal changes in volcanic plume chemistry observed by lunar and solar occultation spectroscopy, Geophys. Res. Lett., 28, 843-846, doi:10.1029/2000gl008499, 2001.

Businger, S., Huff, R., Pattantyus, A., Horton, K., Sutton, A. J., Elias, T., and Cherubini, T.: Observing and Forecasting Vog Dispersion from Kỉlauea Volcano, Hawaii, B. Am. Meteorol. Soc., 96, 1667-1686, doi:10.1175/BAMS-D-14-00150.1, 2015.

Chavez-Demoulin, V. and Davison, A. C.: Generalized additive modelling of sample extremes, J. Roy. Stat. Soc. C App., 54, 207-222, doi:10.1111/j.1467-9876.2005.00479.x, 2005.

Ebmeier, S. K., Sayer, A. M., Grainger, R. G., Mather, T. A., and Carboni, E.: Systematic satellite observations of the impact of aerosols from passive volcanic degassing on local cloud properties, Atmos. Chem. Phys., 14, 10601-10618, doi:10.5194/acp14-10601-2014, 2014.

Fountoukis, C. and Nenes, A.: ISORROPIA II: a computationally efficient thermodynamic equilibrium model for $\mathrm{K}^{+}-$ $\mathrm{Ca}^{2+}-\mathrm{Mg}^{2+}-\mathrm{NH}_{4}^{+}-\mathrm{Na}^{+}-\mathrm{SO}_{4}^{2-}-\mathrm{NO}_{3}^{-}-\mathrm{Cl}^{-}-\mathrm{H}_{2} \mathrm{O}$ aerosols, Atmos. Chem. Phys., 7, 4639-4659, doi:10.5194/acp-7-4639-2007, 2007.

Fowler, D., Smith, R., Muller, J., Cape, J. N., Sutton, M., Erisman, J. W., and Fagerli, H.: Long term trends in sulphur and nitrogen deposition in Europe and the cause of non-linearities, in: Acid Rain - Deposition to Recovery, 41-47, 2007.

Gauci, V., Blake, S., Stevenson, D. S., and Highwood, E. J.: Halving of the northern wetland $\mathrm{CH}(4)$ source by a large Icelandic volcanic eruption, J. Geophys. Res., 113, G00A11, doi:10.1029/2007jg000499, 2008.

Gettelman, A., Schmidt, A., and Egill Kristjansson, J.: Icelandic volcanic emissions and climate, Nat. Geosci., 8, 243-243, doi:10.1038/ngeo2376, 2015. 
Gíslason, S. R., Stefánsdóttir, G., Pfeffer, M. A., Barsotti, S., Jóhannsson, T., Galeczka, I., Bali, E., Sigmarsson, O., Stefánsson, A., Keller, N. S., Sigurdsson, Á., Bergsson, B., Galle, B., Jacobo, V. C., Arellano, S., Aiuppa, A., Jónasdóttir, E. B., Eiríksdóttir, E. S., Jakobsson, S., Guðfinnsson, G. H., Halldórsson, S. A., Gunnarsson, H., Haddadi, B., Jónsdóttir, I., Thordarson, T., Riishuus, M., Högnadóttir, T., Dürig, T., Pedersen, G. B. M., Höskuldsson, Á., and Gudmundsson, M. T.: Environmental pressure from the 2014-15 eruption of Bárðarbunga volcano, Iceland, Geochemical Perspectives Letters, 1, 84-93, doi:10.7185/geochemlet.1509, 2015.

Grahn, H., von Schoenberg, P., and Brännström, N.: What's that smell? Hydrogen sulphide transport from Bardarbunga to Scandinavia, J. Volcanol. Geoth. Res., 303, 187-192, doi:10.1016/j.jvolgeores.2015.07.006, 2015.

Grainger, R. G. and Highwood, E. J.: Changes in stratospheric composition, chemistry, radiation and climate caused by volcanic eruptions, Geol. Soc. Spec. Publ., 213, 329-347, doi:10.1144/gsl.sp.2003.213.01.20, 2003

Hamed, A., Joutsensaari, J., Mikkonen, S., Sogacheva, L., Dal Maso, M., Kulmala, M., Cavalli, F., Fuzzi, S., Facchini, M. C., Decesari, S., Mircea, M., Lehtinen, K. E. J., and Laaksonen, A.: Nucleation and growth of new particles in Po Valley, Italy, Atmos. Chem. Phys., 7, 355-376, doi:10.5194/acp-7-355-2007, 2007.

Horrocks, L. A., Oppenheimer, C., Burton, M. R., and Duffell, H. J.: Compositional variation in tropospheric volcanic gas plumes: evidence from ground-based remote sensing, in: Volcanic Degassing, edited by: Oppenheimer, C., Pyle, D. M., and Barclay, J., Geol. Soc. Spec. Publ., 349-369, 2003.

Hunton, D. E., Viggiano, A. A., Miller, T. M., Ballenthin, J. O., Reeves, J. M., Wilson, J. C., Lee, S. H., Anderson, B. E., Brune, W. H., Harder, H., Simpas, J. B., and Oskarsson, N.: In-situ aircraft observations of the 2000 Mt. Hekla volcanic cloud: Composition and chemical evolution in the Arctic lower stratosphere, J. Volcanol. Geoth. Res., 145, 23-34, doi:10.1016/j.jvolgeores.2005.01.005, 2005.

Ialongo, I., Hakkarainen, J., Kivi, R., Anttila, P., Krotkov, N. A., Yang, K., Li, C., Tukiainen, S., Hassinen, S., and Tamminen, J.: Comparison of operational satellite $\mathrm{SO}_{2}$ products with groundbased observations in northern Finland during the Icelandic Holuhraun fissure eruption, Atmos. Meas. Tech., 8, 2279-2289, doi:10.5194/amt-8-2279-2015, 2015.

Irwin, J. G., Campbell, G., and Vincent, K.: Trends in sulphate and nitrate wet deposition over the United Kingdom: 19861999, Atmos. Environ., 36, 2867-2879, doi:10.1016/S13522310(02)00096-1, 2002.

Khlystov, A., Wyers, G. P., and Slanina, J.: The steam-jet aerosol collector, Atmos. Environ., 29, 2229-2234, doi:10.1016/13522310(95)00180-7, 1995.

Kroll, J. H., Cross, E. S., Hunter, J. F., Pai, S., Wallace, L. M. M., Croteau, P. L., Jayne, J. T., Worsnop, D. R., Heald, C. L., Murphy, J. G., and Frankel, S. L.: Atmospheric Evolution of Sulfur Emissions from Kīlauea: Real-Time Measurements of Oxidation, Dilution, and Neutralization within a Volcanic Plume, Environmental Science \& Technology, 49, 4129-4137, doi:10.1021/es506119x, 2015.

Kulmala, M., Toivonen, A., MÄKelÄ, J. M., and Laaksonen, A. R. I.: Analysis of the growth of nucleation mode particles observed in Boreal forest, Tellus B, 50, 449-462, doi:10.1034/j.16000889.1998.t01-4-00004.x, 1998.

Kulmala, M., Petäjä, T., Mönkkönen, P., Koponen, I. K., Dal Maso, M., Aalto, P. P., Lehtinen, K. E. J., and Kerminen, V.-M.: On the growth of nucleation mode particles: source rates of condensable vapor in polluted and clean environments, Atmos. Chem. Phys., 5, 409-416, doi:10.5194/acp-5-409-2005, 2005.

Makkonen, U., Virkkula, A., Mäntykent”a, J., Hakola, H., Keronen, P., Vakkari, V., and Aalto, P. P.: Semi-continuous gas and inorganic aerosol measurements at a Finnish urban site: comparisons with filters, nitrogen in aerosol and gas phases, and aerosol acidity, Atmos. Chem. Phys., 12, 5617-5631, doi:10.5194/acp12-5617-2012, 2012.

Martin, R. S., Mather, T. A., Pyle, D. M., Power, M., Allen, A. G., Aiuppa, A., Horwell, C. J., and Ward, E. P. W. Composition-resolved size distributions of volcanic aerosols in the Mt. Etna plumes, J. Geophys. Res.-Atmos., 112, D17211, doi:10.1029/2007jd009648, 2008.

Mather, T. A., Allen, A. G., Oppenheimer, C., Pyle, D. M., and McGonigle, A. J. S.: Size-resolved characterisation of soluble ions in the particles in the tropospheric plume of Masaya volcano, Nicaragua: Origins and plume processing, J. Atmos. Chem., 46, 207-237, doi:10.1023/a:1026327502060, 2003.

Mather, T. A., Pyle, D. M., and Oppenheimer, C.: Tropospheric Volcanic Aerosol, in: Volcanism and the Earth's Atmosphere, American Geophysical Union, 189-212, 2013.

Mather, T. A.: Volcanoes and the environment: Lessons for understanding Earth's past and future from studies of presentday volcanic emissions, J. Volcanol. Geoth. Res., 304, 160-179, doi:10.1016/j.jvolgeores.2015.08.016, 2015.

Northrop, P. J. and Jonathan, P.: Threshold modelling of spatially dependent non-stationary extremes with application to hurricane-induced wave heights, Environmetrics, 22, 799-809, doi:10.1002/env.1106, 2011.

Oppenheimer, C., Tsanev, V. I., Braban, C. F., Cox, R. A., Adams, J. W., Aiuppa, A., Bobrowski, N., Delmelle, P., Barclay, J., and McGonigle, A. J. S.: BrO formation in volcanic plumes, Geochim. Cosmochim. Acta, 70, 2935-2941, doi:10.1016/j.gca.2006.04.001, 2006.

Oppenheimer, C., Kyle, P., Eisele, F., Crawford, J., Huey, G., Tanner, D., Kim, S., Mauldin, L., Blake, D., Beyersdorf, A., Buhr, M., and Davis, D.: Atmospheric chemistry of an Antarctic volcanic plume, J. Geophys. Res.-Atmos., 115, D04303, doi:10.1029/2009jd011910, 2010.

Parry, S., Barker, L., Lewis, M., and Clemas, S.: Hydrological summary for the United Kingdom: September 2014, NERC Centre for Ecology \& Hydrology, Wallingford, UK, 2014.

Pyle, D. M. and Mather, T. A.: Halogens in igneous processes and their fluxes to the atmosphere and oceans from volcanic activity: A review, Chem. Geol., 263, 110-121, doi:10.1016/j.chemgeo.2008.11.013, 2009.

Reich, B. J., Fuentes, M., and Dunson, D. B.: Bayesian Spatial Quantile Regression, J. Am. Stat. Assoc., 106, 6-20, 2011.

Richter, A.: GOME-2 SO2 ATBD - 1 - First draft Algorithm Theoretical Basis Document for the GOME-2 Rapid Volcanic SO2 product, available at: http://www.iup.uni-bremen.de/doas/so2_ alerts/gome2_so2_atbd_091005.pdf, 2009.

Ripepe, M., Marchetti, E., and Ulivieri, G.: Infrasonic monitoring at Stromboli volcano during the 2003 effusive erup- 
tion: Insights on the explosive and degassing process of an open conduit system, J. Geophys. Res.-Sol. Ea.,112, B09207, doi:10.1029/2006jb004613, 2007.

Roberts, T. J., Braban, C. F., Martin, R. S., Oppenheimer, C., Adams, J. W., Cox, R. A., Jones, R. L., and Griffiths, P. T.: Modelling reactive halogen formation and ozone depletion in volcanic plumes, Chem. Geol., 1-4, 151-163, 2009.

Rose, W. I., Millard, G. A., Mather, T. A., Hunton, D. E., Anderson, B., Oppenheimer, C., Thornton, B. F., Gerlach, T. M., Viggiano, A. A., Kondo, Y., Miller, T. M., and Ballenthin, J. O.: Atmospheric chemistry of a 33-34 hour old volcanic cloud from Hekla Volcano (Iceland): Insights from direct sampling and the application of chemical box modeling, J. Geophys. Res.-Atmos., 111, D20206, doi:10.1029/2005jd006872, 2006.

Satsumabayashi, H., Kawamura, M., Katsuno, T., Futaki, K., Murano, K., Carmichael, G. R., Kajino, M., Horiguchi, M., and Ueda, H.: Effects of Miyake volcanic effluents on airborne particles and precipitation in central Japan, J. Geophys. Res.-Atmos., 109, D19202, doi:10.1029/2003JD004204, 2004.

Schmidt, A., Ostro, B., Carslaw, K. S., Wilson, M., Thordarson, T., Mann, G. W., and Simmons, A. J.: Excess mortality in Europe following a future Laki-style Icelandic eruption, Proc. Natl. Acad. Sci., 108, 15710-15715, doi:10.1073/pnas.1108569108, 2011.

Schmidt, A., Carslaw, K. S., Mann, G. W., Rap, A., Pringle, K. J., Spracklen, D. V., Wilson, M., and Forster, P. M.: Importance of tropospheric volcanic aerosol for indirect radiative forcing of climate, Atmos. Chem. Phys., 12, 7321-7339, doi:10.5194/acp-127321-2012, 2012.

Schmidt, A., Witham, C. S., Theys, N., Richards, N. A. D., Thordarson, T., Szpek, K., Feng, W., Hort, M. C., Woolley, A. M., Jones, A. R., Redington, A. L., Johnson, B. T., Hayward, C. L., and Carslaw, K. S.: Assessing hazards to aviation from sulfur dioxide emitted by explosive Icelandic eruptions, J. Geophys. Res.Atmos., 119, 14180-14196, doi:10.1002/2014jd022070, 2014.

Schmidt, A., Leadbetter, S., Theys, N., Carboni, E., Witham, C. S., Stevenson, J. A., Birch, C. E., Thordarson, T., Turnock, S., Barsotti, S., Delaney, L., Feng, W. H., Grainger, R. G., Hort, M. C., Hoskuldsson, A., Ialongo, I., Ilyinskaya, E., Johannsson, T., Kenny, P., Mather, T. A., Richards, N. A. D., and Shepherd, J.: Satellite detection, long-range transport, and air quality impacts of volcanic sulfur dioxide from the 2014-2015 flood lava eruption at Baroarbunga (Iceland), J. Geophys. Res.-Atmos., 120, 9739-9757, doi:10.1002/2015jd023638, 2015.

Seinfeld, J. H. and Pandis, S. N.: Atmospheric Chemistry and Physics: From Air Pollution to Climate Change, Second Edition, 2nd Edn., John Wiley and Sons Inc, Hoboken, New Jersey, 2006.

Simpson, D., Benedictow, A., Berge, H., Bergström, R., Emberson, L. D., Fagerli, H., Flechard, C. R., Hayman, G. D., Gauss, M., Jonson, J. E., Jenkin, M. E., Nyíri, A., Richter, C., Semeena, V. S., Tsyro, S., Tuovinen, J.-P., Valdebenito, Á., and Wind, P.: The EMEP MSC-W chemical transport model - technical description, Atmos. Chem. Phys., 12, 7825-7865, doi:10.5194/acp-127825-2012, 2012.

Sutton, M. A., Tang, Y. S., Miners, B., and Fowler, D.: A New Diffusion Denuder System for Long-Term, Regional Monitoring of Atmospheric Ammonia and Ammonium, Water Air Soil Poll., 1, 145-156, doi:10.1023/a:1013138601753, 2001.
Tang, Y. S., Simmons, I., van Dijk, N., Di Marco, C., Nemitz, E., Daemmgen, U., Gilke, K., Djuricic, V., Vidic, S., Gliha, Z., Borovecki, D., Mitosinkova, M., Hanssen, J. E., Uggerud, T. H., Sanz, M. J., Sanz, P., Chorda, J. V., Flechard, C. R., Fauvel, Y., Ferm, M., Perrino, C., and Sutton, M. A.: European scale application of atmospheric reactive nitrogen measurements in a low-cost approach to infer dry deposition fluxes, Agr. Ecosyst. Environ., 133, 183-195, doi:10.1016/j.agee.2009.04.027, 2009.

Thordarson, T. and Self, S.: Atmospheric and environmental effects of the 1783-1784 Laki eruption: A review and reassessment, J. Geophys. Res.-Atmos., 108, AAC 7-1-AAC 7-29, doi:10.1029/2001jd002042, 2003.

Tørseth, K., Aas, W., Breivik, K., Fjæraa, A. M., Fiebig, M., Hjellbrekke, A. G., Lund Myhre, C., Solberg, S., and Yttri, K. E.: Introduction to the European Monitoring and Evaluation Programme (EMEP) and observed atmospheric composition change during 1972-2009, Atmos. Chem. Phys., 12, 5447-5481, doi:10.5194/acp-12-5447-2012, 2012.

Twigg, M. M., Di Marco, C. F., Leeson, S., van Dijk, N., Jones, M. R., Leith, I. D., Morrison, E., Coyle, M., Proost, R., Peeters, A. N. M., Lemon, E., Frelink, T., Braban, C. F., Nemitz, E., and Cape, J. N.: Water soluble aerosols and gases at a UK background site - Part 1: Controls of $\mathrm{PM}_{2.5}$ and $\mathrm{PM}_{10}$ aerosol composition, Atmos. Chem. Phys., 15, 8131-8145, doi:10.5194/acp-15-81312015, 2015.

Vieno, M., Dore, A. J., Stevenson, D. S., Doherty, R., Heal, M. R., Reis, S., Hallsworth, S., Tarrason, L., Wind, P., Fowler, D., Simpson, D., and Sutton, M. A.: Modelling surface ozone during the 2003 heat-wave in the UK, Atmos. Chem. Phys., 10, 7963-7978, doi:10.5194/acp-10-7963-2010, 2010

Vieno, M., Heal, M. R., Hallsworth, S., Famulari, D., Doherty, R. M., Dore, A. J., Tang, Y. S., Braban, C. F., Leaver, D., Sutton, M. A., and Reis, S.: The role of long-range transport and domestic emissions in determining atmospheric secondary inorganic particle concentrations across the UK, Atmos. Chem. Phys., 14, 8435-8447, doi:10.5194/acp-14-8435-2014, 2014.

Vieno, M., Heal, M. R., Williams, M. L., Carnell, E. J., Nemitz, E., Stedman, J. R., and Reis, S.: The sensitivities of emissions reductions for the mitigation of $\mathrm{UK} \mathrm{PM}_{2.5}$, Atmos. Chem. Phys., 16, 265-276, doi:10.5194/acp-16-265-2016, 2016.

von Glasow, R., Bobrowski, N., and Kern, C.: The effects of volcanic eruptions on atmospheric chemistry, Chem. Geol., 263, 131-142, doi:10.1016/j.chemgeo.2008.08.020, 2009.

von Glasow, R.: Atmospheric chemistry in volcanic plumes, Proc. Natl. Acad. Sci. USA, 107, 6594-6599, doi:10.1073/pnas.0913164107, 2010.

Wiedensohler, A., Birmili, W., Nowak, A., Sonntag, A., Weinhold, K., Merkel, M., Wehner, B., Tuch, T., Pfeifer, S., Fiebig, M., Fjäraa, A. M., Asmi, E., Sellegri, K., Depuy, R., Venzac, H., Villani, P., Laj, P., Aalto, P., Ogren, J. A., Swietlicki, E., Williams, P., Roldin, P., Quincey, P., Hüglin, C., Fierz-Schmidhauser, R., Gysel, M., Weingartner, E., Riccobono, F., Santos, S., Grüning, C., Faloon, K., Beddows, D., Harrison, R., Monahan, C., Jennings, S. G., O’Dowd, C. D., Marinoni, A., Horn, H.-G., Keck, L., Jiang, J., Scheckman, J., McMurry, P. H., Deng, Z., Zhao, C. S., Moerman, M., Henzing, B., de Leeuw, G., Löschau, G., and Bastian, S.: Mobility particle size spectrometers: harmonization of technical standards and data structure to facilitate high quality long-term observations of atmospheric particle number size 
distributions, Atmos. Meas. Tech., 5, 657-685, doi:10.5194/amt5-657-2012, 2012.

Witham, C., Aspinall, W., Braban, C., Hall, J., Loughlin, S., Schmidt, A., Vieno, M., Bealey, B., Hort, M., Ilyinskaya, E., Kentisbeer, J., Roberts, E., and Rowe, E.: UK hazards from a large Icelandic effusive eruption. Effusive Eruption Modelling Project final report, Met Office, Exeter, 226, 2015.
Wyers, G. P., Otjes, R. P., and Slanina, J.: A continuous-flow denuder for the measurement of ambient concentrations and surface-exchange fluxes of ammonia, Atmos. Environ., 27, 2085-2090, doi:10.1016/0960-1686(93)90280-C, 1993.

Zelenski, M., Taran, Y., and Galle, B.: High emission rate of sulfuric acid from Bezymianny volcano, Kamchatka, Geophys. Res. Lett., 42, 7005-7013, doi:10.1002/2015g1065340, 2015. 